\title{
Review of Antibacterial Activity of Titanium-Based Implants' Surfaces Fabricated by Micro-Arc Oxidation
}

\author{
Xiaojing He, Xiangyu Zhang *, Xin Wang and Lin Qin \\ College of Materials Science and Engineering, Taiyuan University of Technology, Taiyuan 030024, China; \\ zxyclw1@126.com (X.H.); wangxin@tyut.edu.cn (X.W.); qinlin@tyut.edu.cn (L.Q.) \\ * Correspondence: zhangxiangyu@tyut.edu.cn; Tel.: +86-351-601-0540
}

Academic Editor: Yuelian Liu

Received: 28 November 2016; Accepted: 14 March 2017; Published: 22 March 2017

\begin{abstract}
Ti and its alloys are the most commonly-used materials for biomedical applications. However, bacterial infection after implant placement is still one of the significant rising complications. Therefore, the application of the antimicrobial agents into implant surfaces to prevent implant-associated infection has attracted much attention. Scientific papers have shown that inorganic antibacterial metal elements (e.g., $\mathrm{Ag}, \mathrm{Cu}, \mathrm{Zn}$ ) can be introduced into implant surfaces with the addition of metal nanoparticles or metallic compounds into an electrolyte via micro-arc oxidation (MAO) technology. In this review, the effects of the composition and concentration of electrolyte and process parameters (e.g., voltage, current density, oxidation time) on the morphological characteristics (e.g., surface morphology, bonding strength), antibacterial ability and biocompatibility of MAO antimicrobial coatings are discussed in detail. Anti-infection and osseointegration can be simultaneously accomplished with the selection of the proper antibacterial elements and operating parameters. Besides, MAO assisted by magnetron sputtering (MS) to endow Ti-based implant materials with superior antibacterial ability and biocompatibility is also discussed. Finally, the development trend of MAO technology in the future is forecasted.
\end{abstract}

Keywords: micro-arc oxidation; antibacterial ability; $\mathrm{Ag} ; \mathrm{Cu}$; $\mathrm{Zn}$

\section{Introduction}

Biomedical titanium (Ti) and its alloys have been widely used in blood vessels, artificial joints, dental implantations and bone screws [1-3] on account of their excellent mechanical properties, good corrosion resistance and favorable biocompatibility. However, implant-associated infection (IAI) remains one of the most devastating postoperative complications $[4,5]$ despite strict sterilization and systemic antibiotic prophylaxis prior to surgery. IAI often commences with bacterial adhesion to the implant and colonization on the implant surface, followed by biofilm formation. The biofilms are extraordinarily resistant to antibiotics and the host immunity defensive system [6-8], leading to further complications. Once the biofilm is formed, it is often not effectively treated except for prosthesis removal and re-implantation $[9,10]$. This devastating complication may result in chronic suffering and extremely huge medical expenses [11,12]. Therefore, it is highly desirable to introduce antimicrobial agents into implant surfaces to provide antibacterial activities and prevent peri-implant infections [13-17]. In comparison with organic antibiotics, inorganic antibacterial metal elements (e.g., silver $(\mathrm{Ag})$ [18-22], copper $(\mathrm{Cu})$ [23-26] and zinc $(\mathrm{Zn})$ [27-29]) have attracted great attention due to their perfect stabilities, superior broad-spectrum antibacterial properties, relatively low toxicity to human cells and low risk of producing resistant strains [30,31].

Dizaj et al. [32] have reviewed the antimicrobial activity of metal and metal oxide nanoparticles together with their antimicrobial mechanisms and have indicated that the particle size determined the antimicrobial effectiveness of the metal nanoparticles. Rai et al. [33] have extensively reviewed 
the antibacterial, antifungal and antiviral properties of Ag ions, $\mathrm{Ag}$ compounds and $\mathrm{Ag}$ nanoparticles, but there is no discussion about the antibacterial properties of $\mathrm{Cu}$ or $\mathrm{Zn}$. In addition, the toxicities of metal and metal oxide nanoparticles to apply as proper alternatives for antibiotics in biomedical applications were not discussed in the reviews. In order to obtain antibacterial metallic surfaces, numerous surface modifications have been performed. Ferraris et al. [34] have reported the surface modification technologies, such as ion implantation [35,36], ion beam-assisted deposition [37], electrochemical techniques [38], ion exchange [39], sol-gel [40], sputtering [41,42], plasmas pray [43] and chemical vapor deposition [44]. However, micro-arc oxidation (MAO) is not fully described.

$\mathrm{MAO}$, which can produce porous, adhesive and bioactive coatings for implantation, has aroused considerable attention [45-47]. On the one hand, a porous bioactive calcium phosphate-based composite layer can be deposited on Ti-based implant surfaces according to the selected electrolyte, which would enhance the biocompatibility $[48,49]$ and the bonding strength of the coated layer [50]. On the other hand, antibacterial metal elements can be incorporated into implant surfaces to inhibit initial adhesion of bacteria and prevent post-surgery complications, thus enhancing the antibacterial property [34]. Furthermore, the content of bioactive elements and antibacterial metal elements on the MAO coating surface can be tuned by controlling voltage, electrolyte components and MAO time [51]. To our best knowledge, this specific topic has not been reviewed in the recent literature. The aim of the review is to collect and compare the recent scientific papers concerning surface modification of Ti with the incorporation of antibacterial metal elements (e.g., $\mathrm{Ag}, \mathrm{Cu}, \mathrm{Zn}$ ) to endow antibacterial properties by MAO. The review focuses mainly on the effects of the composition and concentration of electrolyte and process parameters (voltage, current density, oxidation time) on the morphological characteristics, antibacterial ability and biocompatibility of MAO coating. MAO assisted by magnetron sputtering (MS) to achieve a superior antibacterial property and biocompatibility is also discussed, following the forecast of the development trend of MAO in the future.

\section{Micro-Arc Oxidation Method}

MAO, which is also referred to as plasma electrolyte oxidation (PEO), is a high voltage plasma-assisted anodic oxidation process. MAO is a relatively convenient technique for forming firmly adherent oxide ceramic layers on the surfaces of valve metal, such as $\mathrm{Ti}, \mathrm{Al}, \mathrm{Mg}, \mathrm{Zr}, \mathrm{Ta}$ and their alloys. As shown in Figure 1, the MAO process was controlled by an MAO power supply. Before $\mathrm{MAO}$, the non-working side of the specimen was connected with a copper conductor and coated with acrylate adhesive. During the MAO process, the specimen was treated as the anode, and the stainless steel electrolytic bath was regarded as the cathode to fill with electrolyte. The stirrer was applied to keep the electrolyte uniform, and the circulating water treatment system was used to sustain the temperature of the electrolyte below $30^{\circ} \mathrm{C}$.

The principle of MAO is explained in Figure 2. At the initial stage of MAO treatment, as soon as the specimen is exposed to the electrolyte, the voltage increases rapidly and linearly with time, and an anodic barrier film, also called a passivating film (Figure 2a), is initially formed on the surface of the specimen. Soon afterwards, with the increase of voltage, some tiny oxygen bubbles can be observed, and a porous insulating oxide layer, which usually grows under conditions of dielectric breakdown, forms on the surface of the specimen [52]. At this stage, the voltage and current flow follow Faraday's law, which corresponds to the conventional anodizing stage (Figure $2 b$ ). When the applied voltage on the specimen surpasses the dielectric breakdown of the insulating oxide coating, dielectric breakdown takes place, leading to the formation of spark discharges (Figure 2c). The current flow only concentrates on regions of breakdown, and the $\mathrm{Ca}$ and $\mathrm{P}$ elements from the electrolyte and the other elements from the specimen enter into regions of breakdown by diffusion and electrophoresis at intense local high temperatures, resulting in localized forming and thickening of the porous structure oxide coating. The discharge sparks gradually grow bigger, and the micro-arcs' discharges are transformed into powerful arc discharges (Figure 2d). When the new generated oxide coating (Figure 2e) is capable of resisting current flow, the other regions are vulnerable to breakdown due to the smaller resistance, and 
finally, the chemical reaction interface would move towards the entire surface [53]. Breakdown of the coating occurs at a vulnerable spot of the growing oxide film. Meanwhile, the new porous structure oxide coating might also be formed and thickened by the emission of gas due to intense local high temperatures at the sites of breakdown [54]. With the prolonging of oxidation time, large discharge channels with intense sparking and gas bubbles would emerge at the surface, leading to the formation of larger protruding pores, even a spongy interconnected microstructure (Figure 2f). The continuous formation and breakdown of the oxide coating (Figure $2 \mathrm{~g}$ ) causes the potential to fluctuate. Both the dissolution of the base material and gasification of the electrolyte enable the formation of the porous ceramic oxide coating (Figure 2h).



Figure 1. Schematic diagram of the micro-arc oxidation (MAO) experimental device.
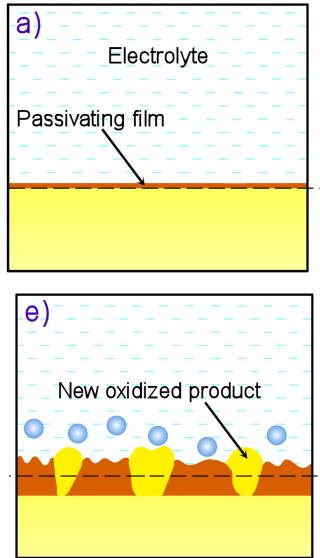
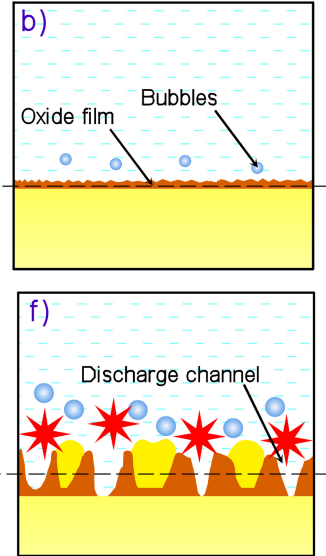



Figure 2. Schematic of the formation process of MAO porous coating. The passivating film (a), and porous insulating oxide film (b) is initially formed. Then under the action of the spark discharges (c) and, powerful arc discharges (d), the new generated oxide coating (e) is formed and thicken. Finally, the porous ceramic oxide coating is formed $(\mathbf{h})$ with the continuous formation and breakdown of the oxide coating $(\mathrm{g})$ at the large discharge channels (f).

The composition of the MAO electrolytes has a dramatic effect on the morphological characteristics, such as the porosity and thickness of MAO coatings. Hence, the proper selection of the electrolyte composition is imperative to obtain satisfactory performance. Generally, different antibacterial metal elements mixed with calcium acetate (CA) and glycerophosphate disodium (GP) are used as the base electrolyte in the MAO process to enhance the antibacterial property of the implant materials. The characteristics of the fabricated antibacterial coating prepared by MAO techniques are briefly summarized in Table 1, and the details are reviewed according to the difference of the doping method of the antibacterial metal elements. 
Table 1. Summary of the characteristics of antibacterial coating by MAO.

\begin{tabular}{|c|c|c|c|c|c|c|c|c|c|c|c|}
\hline \multirow[b]{2}{*}{ Ti Alloy } & \multirow[b]{2}{*}{ Electrolyte } & \multicolumn{3}{|c|}{ Electrical Parameter } & \multirow[b]{2}{*}{$\begin{array}{l}\text { Surface Topography } \\
\text { (Pore Size) }\end{array}$} & \multirow[b]{2}{*}{$\begin{array}{l}\text { XRD Detected } \\
\text { Phase }\end{array}$} & \multirow[b]{2}{*}{$\begin{array}{l}\text { Surface Content } \\
\text { of } \mathrm{Ag} / \mathrm{Cu} / \mathrm{Zn} \\
(\mathrm{wt} \%)\end{array}$} & \multirow{2}{*}{$\begin{array}{c}\text { Release } \\
\text { Amount of } \\
\mathrm{Ag} / \mathrm{Cu} / \mathrm{Zn} \\
(\mathrm{ppb})\end{array}$} & \multirow[b]{2}{*}{$\begin{array}{c}\text { Tested } \\
\text { Bacteria }\end{array}$} & \multirow[b]{2}{*}{ Biocompatibility } & \multirow[b]{2}{*}{ References } \\
\hline & & $\begin{array}{l}\text { Voltage } \\
\text { (V) }\end{array}$ & $\begin{array}{c}\text { Current } \\
\text { Density } \\
\left(\mathrm{A} \cdot \mathrm{dm}^{-2}\right)\end{array}$ & $\begin{array}{l}\text { Oxidation } \\
\text { Time (s) }\end{array}$ & & & & & & & \\
\hline Ti-6Al-7Nb & $\begin{array}{l}0.02 \mathrm{M} \mathrm{Ca}-\mathrm{GP}, 0.15 \mathrm{M} \mathrm{CA}, \\
\text { and } 3.0 \mathrm{~g} \cdot \mathrm{L}^{-1} \mathrm{Ag} \mathrm{NPs}\end{array}$ & $<250$ & 20 & 300 & $\begin{array}{l}\text { Porous structures }(<3 \mu \mathrm{m}) \\
\text { with Ag NP of } 37 \mathrm{~nm}\end{array}$ & $\begin{array}{l}\text { Ti, rutile and } \\
\text { anatase }\end{array}$ & 0.03 & - & S. aureus & - & [55] \\
\hline Ti-6Al-7Nb & $\begin{array}{l}0.02 \mathrm{M} \mathrm{Ca}-\mathrm{GP}, 0.15 \mathrm{M} \mathrm{CA}, \\
\text { and } 3.0 \mathrm{~g} \cdot \mathrm{L}^{-1} \mathrm{Ag} \mathrm{NPs}\end{array}$ & $<250$ & 20 & $0-300$ & $\begin{array}{l}\text { Porous structures }(<5 \mu \mathrm{m}) \\
\text { with Ag NP of } 7-25 \mathrm{~nm}\end{array}$ & - & - & - & - & - & [56] \\
\hline Ti-6Al-7Nb & $\begin{array}{l}0.02 \mathrm{M} \mathrm{Ca}-\mathrm{GP}, 0.15 \mathrm{M} \mathrm{CA}, \\
\text { and } 0.3 \mathrm{~g} \cdot \mathrm{L}^{-1} \mathrm{Ag} \mathrm{NPs}\end{array}$ & $234 \pm 3$ & 20 & 300 & Porous structures $(<5 \mu \mathrm{m})$ & - & - & 12 & S. aureus & $\begin{array}{c}\text { Human } \\
\text { osteoblastic cell } \\
\end{array}$ & [38] \\
\hline Ti-6Al-7Nb & $\begin{array}{l}0.02 \mathrm{M} \mathrm{Ca}-\mathrm{GP}, 0.15 \mathrm{M} \mathrm{CA}, \\
\text { and } 3.0 \mathrm{~g} \cdot \mathrm{L}^{-1} \mathrm{Ag} \mathrm{NPs}\end{array}$ & $237 \pm 2$ & 20 & 300 & Porous structures $(<5 \mu \mathrm{m})$ & - & - & 89 & S. aureus & $\begin{array}{c}\text { Human } \\
\text { osteoblastic cell }\end{array}$ & [38] \\
\hline Cp-Ti & $\begin{array}{c}2 \mathrm{~g} \cdot \mathrm{L}^{-1} \mathrm{NaOH}, 15 \mathrm{~g} \cdot \mathrm{L}^{-1} \\
\mathrm{NaH}_{2} \mathrm{PO}_{4} \text { and } 3.0 \mathrm{~g} \cdot \mathrm{L}^{-1} \mathrm{Cu} \text { NPs }\end{array}$ & - & 20 & 300 & $\begin{array}{l}\text { Porous structures }(<5 \mu \mathrm{m}) \\
\text { with } \mathrm{Cu} \mathrm{NP} \text { of } 60 \mathrm{~nm}\end{array}$ & - & - & - & $\begin{array}{l}\text { Escherichia } \\
\quad \text { coli, } \\
\text { S. aureus }\end{array}$ & - & [57] \\
\hline Cp-Ti & $\begin{array}{c}0.04 \mathrm{M} \beta \text {-GP, } 0.4 \mathrm{M} \mathrm{CA} \text { and } \\
0.004 \mathrm{MgNO}_{3}\end{array}$ & $250-350$ & - & 180 & Spherical pores $(<3 \mu \mathrm{m})$ & $\begin{array}{l}\text { Ti, rutile, and } \\
\text { anatase }\end{array}$ & - & - & S. aureus & $\begin{array}{l}\text { Human } \\
\text { osteosarcoma } \\
\text { (HOS) cell }\end{array}$ & [58] \\
\hline Cp-Ti & $\begin{array}{c}0.04 \mathrm{M} \beta \text {-GP, } 0.4 \mathrm{M} \mathrm{CA} \text { and } \\
0.004 \mathrm{M} \mathrm{AgNO}_{3}\end{array}$ & 420 & - & 180 & $\begin{array}{l}\text { Irregular and rough pores } \\
\text { with spherical particles } \\
\text { and flake }\end{array}$ & $\begin{array}{c}\text { Rutile, } \\
\beta-\mathrm{Ca}_{2} \mathrm{P}_{2} \mathrm{O}_{7} \\
\alpha-\mathrm{TCP} \text { and } \mathrm{HA}\end{array}$ & $0.21-0.45$ & - & S. aureus & $\begin{array}{l}\text { Human } \\
\text { osteosarcoma } \\
\text { (HOS) cell }\end{array}$ & [58] \\
\hline Cp-Ti & $\begin{array}{c}0.04 \mathrm{M} \beta \text {-GP, } 0.4 \mathrm{M} \mathrm{CA} \text { and } \\
0.00006 \mathrm{M} \mathrm{AgNO}_{3}\end{array}$ & 420 & - & 180 & $\begin{array}{l}\text { Irregular and rough pores } \\
\text { with spherical particles } \\
\text { and flake }\end{array}$ & $\begin{array}{c}\text { Rutile, } \\
\beta-\mathrm{Ca}_{2} \mathrm{P}_{2} \mathrm{O}_{7} \\
\alpha-\mathrm{TCP} \text { and HA }\end{array}$ & 0.1 & - & S. aureus & $\begin{array}{l}\text { Human } \\
\text { osteosarcoma } \\
\text { (HOS) cell }\end{array}$ & [58] \\
\hline Ti6Al4V & $\beta$-GP, $\mathrm{CA}$ and $0.1 \mathrm{~g} \cdot \mathrm{L}^{-1} \mathrm{AgNO}_{3}$ & 400 & - & 300 & $\begin{array}{c}\text { Granular } \\
\text { morphology with Ag NPs } \\
\text { of } 20-30 \mathrm{~nm}\end{array}$ & $\begin{array}{c}\mathrm{Ti}, \text { rutile, } \\
\text { anatase, } \\
\mathrm{CaTiO}_{3} \text { and } \mathrm{HA}\end{array}$ & 0.6 & 2500 & E. coli & - & [59] \\
\hline Ti6Al4V & $\beta$-GP, $\mathrm{CA}$ and $0.4 \mathrm{~g} \cdot \mathrm{L}^{-1} \mathrm{AgNO}_{3}$ & 400 & - & 300 & $\begin{array}{l}\text { Needle-like morphology } \\
\text { with Ag NPs of } 20-30 \mathrm{~nm}\end{array}$ & $\begin{array}{c}\mathrm{Ti}, \text { rutile, } \\
\text { anatase, } \\
\mathrm{CaTiO}_{3} \text { and } \mathrm{HA}\end{array}$ & 2.1 & 8000 & E. coli & - & [59] \\
\hline Cp-Ti & $\begin{array}{c}\mathrm{Na}_{2} \mathrm{HPO}_{4}, \mathrm{CA} \text {, and } 0.0025 \mathrm{M} \\
\mathrm{CH}_{3} \mathrm{COOAg}\end{array}$ & 380 & - & 300 & $\begin{array}{c}\text { Flake-like morphology } \\
\text { with regional Ag particles } \\
\text { less than } 200 \mathrm{~nm}\end{array}$ & $\begin{array}{c}\mathrm{Ti} \text {, rutile, } \\
\text { anatase, } \\
\mathrm{CaTiO}_{3} \text { and } \mathrm{HA}\end{array}$ & 4.6 & - & $\begin{array}{l}\text { E. coli, } \\
\text { S. aureus }\end{array}$ & - & [60] \\
\hline Cp-Ti & $0.5-1.0 \mathrm{~g} \cdot \mathrm{L}^{-1} \mathrm{AgNO}_{3}$ & - & 65 & $5-240$ & $\begin{array}{l}\text { Highly ordered nanopores } \\
\text { with Ag NPs of } 10-30 \mathrm{~nm} \\
\text { within micropits }\end{array}$ & - & - & $200-450$ & S. aureus & $\begin{array}{c}\text { Newborn mouse } \\
\text { pre-osteoblast } \\
\text { cells }\end{array}$ & [61] \\
\hline Cp-Ti & $\begin{array}{c}7.6 \mathrm{~g} \cdot \mathrm{L}^{-1} \mathrm{Na}_{3} \mathrm{PO}_{4}, 9.4 \mathrm{~g} \cdot \mathrm{L}^{-1} \\
\mathrm{Ca}\left(\mathrm{NO}_{3}\right)_{2} \text { and } 1.0 \mathrm{~g} \cdot \mathrm{L}^{-1} \mathrm{AgNO}_{3}\end{array}$ & - & 65 & 240 & $\begin{array}{c}\text { Highly ordered nanopores } \\
\text { with Ag NPs of } 10-30 \mathrm{~nm} \\
\text { within micropits }\end{array}$ & - & - & - & S. aureus & $\begin{array}{l}\text { Newborn mouse } \\
\text { pre-osteoblast } \\
\text { cells }\end{array}$ & [61] \\
\hline
\end{tabular}


Table 1. Cont.

\begin{tabular}{|c|c|c|c|c|c|c|c|c|c|c|c|}
\hline \multirow[b]{2}{*}{ Ti Alloy } & \multirow[b]{2}{*}{ Electrolyte } & \multicolumn{3}{|c|}{ Electrical Parameter } & \multirow[b]{2}{*}{$\begin{array}{l}\text { Surface Topography } \\
\quad \text { (Pore Size) }\end{array}$} & \multirow[b]{2}{*}{$\begin{array}{l}\text { XRD Detected } \\
\text { Phase }\end{array}$} & \multirow[b]{2}{*}{$\begin{array}{l}\text { Surface Content } \\
\text { of } \mathrm{Ag} / \mathrm{Cu} / \mathrm{Zn} \\
\text { (wt \%) }\end{array}$} & \multirow{2}{*}{$\begin{array}{c}\text { Release } \\
\text { Amount of } \\
\text { Ag/Cu/Zn } \\
\text { (ppb) }\end{array}$} & \multirow[b]{2}{*}{$\begin{array}{c}\text { Tested } \\
\text { Bacteria }\end{array}$} & \multirow[b]{2}{*}{ Biocompatibility } & \multirow[b]{2}{*}{ References } \\
\hline & & $\begin{array}{l}\text { Voltage } \\
\text { (V) }\end{array}$ & $\begin{array}{l}\text { Current } \\
\text { Density } \\
\left(\mathrm{A} \cdot \mathrm{dm}^{-2}\right)\end{array}$ & $\begin{array}{l}\text { Oxidation } \\
\text { Time (s) }\end{array}$ & & & & & & & \\
\hline Cp-Ti & $1.0 \sim 8.0 \mathrm{~g} \cdot \mathrm{L}^{-1} \mathrm{Cu}\left(\mathrm{NO}_{3}\right)_{2}$ & - & 65 & 240 & $\begin{array}{l}\text { Mesopores (20-40 nm) } \\
\text { within micropits }\end{array}$ & $\mathrm{Ti}$ & - & - & - & Osteoblast cells & [62] \\
\hline Cp-Ti & $\begin{array}{c}3.8 \sim 7.6 \mathrm{~g} \cdot \mathrm{L}^{-1} \mathrm{Na}_{3} \mathrm{PO}_{4} \text { and } \\
1.0 \mathrm{~g} \cdot \mathrm{L}^{-1} \mathrm{Cu}\left(\mathrm{NO}_{3}\right)_{2}\end{array}$ & - & 65 & 240 & $\begin{array}{l}\text { Mesopores (20-40 nm) } \\
\text { within micropits }\end{array}$ & $\mathrm{Ti}$ & - & - & - & Osteoblast cells & [62] \\
\hline Cp-Ti & $\begin{array}{c}0.05 \mathrm{M} \beta-\mathrm{GP}, 0.1 \mathrm{M} \mathrm{CA} \text { and } \\
0.05 \mathrm{M}\left(\mathrm{CH}_{3} \mathrm{COO}\right)_{2} \mathrm{Cu}\end{array}$ & - & 16.5 & 240 & $\begin{array}{l}\text { Micropores or crater } \\
\text { structures }(3-5 \mu \mathrm{m}) \text { with } \\
\text { nano-grains of } 30-50 \mathrm{~nm}\end{array}$ & Ti and anatase & 1.43 & - & S. aureus & $\begin{array}{l}\text { Human } \\
\text { osteosarcoma cell }\end{array}$ & [63] \\
\hline Cp-Ti & $\begin{array}{c}0.02 \mathrm{M} \beta-\mathrm{GP}, 0.2 \mathrm{M} \mathrm{CA} \text { and } \\
0.00125 \sim 0.005 \mathrm{M} \mathrm{Cu} \\
\left(\mathrm{CH}_{3} \mathrm{COO}\right)_{2}\end{array}$ & 450 & - & 90 & $\begin{array}{l}\text { Micropore structures } \\
\qquad(1-4 \mu \mathrm{m})\end{array}$ & $\begin{array}{c}\text { Rutile and } \\
\text { anatase }\end{array}$ & $0.67-1.93$ & $2.8-60.2$ & S. aureus & $\begin{array}{l}\text { Mouse fibroblast } \\
\text { cell }\end{array}$ & [64] \\
\hline Cp-Ti & $\begin{array}{c}0.15 \mathrm{M} \mathrm{Ca}-G P, 0.02 \mathrm{M} \mathrm{CA} \text { and } \\
0.06 \mathrm{M} \mathrm{ZA}\end{array}$ & - & 30 & 300 & Porous structures $(<5 \mu \mathrm{m})$ & $\begin{array}{l}\text { Ti, rutile and } \\
\text { anatase }\end{array}$ & 8.7 & - & $\begin{array}{l}\text { E. coli, } S \text {. } \\
\text { aureus }\end{array}$ & Osteoblast cells & [65] \\
\hline Cp-Ti & $\begin{array}{c}0.05 \mathrm{M} \beta \text {-GP, } 0.1 \mathrm{M} \mathrm{CA} \text { and } \\
0.02 \sim 0.06 \mathrm{ZA}\end{array}$ & - & 16.5 & 240 & $\begin{array}{c}\text { Microporous structures } \\
(<5 \mu \mathrm{m})\end{array}$ & - & $4.6-9.3$ & $1000-3620$ & $\begin{array}{l}\text { E. coli, } S \text {. } \\
\text { aureus }\end{array}$ & $\begin{array}{l}\text { Rat bone } \\
\text { mesenchymal } \\
\text { stem cells }\end{array}$ & {$[10]$} \\
\hline Cp-Ti & $\begin{array}{c}0.02 \mathrm{M} \beta \text {-GP, } 0.1 \mathrm{M} \mathrm{CA}, 0.1 \mathrm{M} \\
\mathrm{ZA} \text {, and } 6 \mathrm{~g} \cdot \mathrm{L}^{-1} \mathrm{Ag} \text { NPs }\end{array}$ & 390 & - & $30-90$ & $\begin{array}{l}\text { Microporous structures } \\
(1-4 \mu \mathrm{m})\end{array}$ & $\begin{array}{c}\text { Anatase and } \\
\text { rutile }\end{array}$ & $\begin{array}{c}1.06-1.42(\mathrm{Ag}) \\
22.19-26.93(\mathrm{Zn})\end{array}$ & - & S. aureus & - & [66] \\
\hline Cp-Ti & $\begin{array}{c}0.02 \mathrm{M} \beta-\mathrm{GP}, 0.1 \mathrm{M} \mathrm{CA}, 0.1 \mathrm{M} \\
\mathrm{ZA} \text {, and } 6 \mathrm{~g} \cdot \mathrm{L}^{-1} \mathrm{Ag} \text { NPs }\end{array}$ & 390 & - & 120 & $\begin{array}{c}\text { Microporous structures } \\
(1-4 \mu \mathrm{m}) \text { with Ag NPs of } \\
5-10 \mathrm{~nm}\end{array}$ & $\begin{array}{l}\text { Anatase, rutile } \\
\text { and } \mathrm{ZnO}\end{array}$ & $\begin{array}{c}1.56(\mathrm{Ag}), 29.38 \\
(\mathrm{Zn})\end{array}$ & $\begin{array}{l}684(\mathrm{Ag}) \\
6880(\mathrm{Zn})\end{array}$ & S. aureus & - & {$[66]$} \\
\hline Cp-Ti & $\begin{array}{c}0.02 \mathrm{M} \beta-\mathrm{GP}, 0.1 \mathrm{MCA}, 0.1 \mathrm{M} \\
\mathrm{ZA} \text {, and } 6 \mathrm{~g} \cdot \mathrm{L}^{-1} \mathrm{Ag} \mathrm{NPs}\end{array}$ & 390 & - & 240 & $\begin{array}{l}\text { Microporous structures } \\
(1-4 \mu \mathrm{m}) \text { with } \\
\text { some deposits }\end{array}$ & $\begin{array}{l}\text { Anatase, rutile, } \\
\mathrm{ZnO} \text { and } \\
\mathrm{Zn}_{2} \mathrm{TiO}_{4}\end{array}$ & $\begin{array}{c}1.58(\mathrm{Ag}), 31.27 \\
(\mathrm{Zn})\end{array}$ & - & S. aureus & - & {$[66]$} \\
\hline
\end{tabular}

Notes: GP: Glycerophosphate; CA: Calcium acetate; $\alpha$-TCP: $\mathrm{Ca}_{3}(\mathrm{PO} 4)_{2} ; \mathrm{HA}: \mathrm{Ca} 10(\mathrm{PO} 4)_{6}(\mathrm{OH})_{2}$. 


\subsection{Introduction of Metal Nanoparticles into MAO Electrolyte}

NPs present a greater chemical activity than the bulk material for the advantage of their larger ratio of surface area to volume [67]. Ag NPs are the most popular inorganic antimicrobial NPs [68] and can be incorporated into implants by direct dispersion of solid Ag NPs in the electrolyte during MAO. The antibacterial mechanisms as reported are that Ag NPs can directly interact with the microbial cells, leading to the increase of membrane permeability [69], the degradation of lipopolysaccharide molecules with the formation of pits and gaps in the bacterial membrane and the damage of the bacterial outer membrane [70,71]. Ag NPs can also penetrate the bacterial cell envelope and cause DNA damage and protein oxidation by producing secondary products, such as reactive oxygen species [72]. It has also been demonstrated that the antimicrobial activity of Ag NPs is higher than that of Ag ion [73]. The use of Ag NPs will lead to anti-bacterial effects maximized due to the increased numbers of particles per unit area [67].

Necula et al. [55] have successfully fabricated Ag-bearing $\mathrm{TiO}_{2}$ coatings with different contents of Ag NPs by MAO in the electrolyte, including CA, calcium glycerophosphate (Ca-GP) with Ag NPs. The morphology of metallic Ag NPs is similar to that of the particles in the electrolyte [56]. The average size of Ag NPs was measured to be $37 \pm 6 \mathrm{~nm}$. Under the assistance of electrophoresis during MAO, Ag NPs were homogeneously absorbed on the porous surface (Figure 3a,d) [38], transmitted to the inner pore walls of the titanium oxide along the short-circuit paths (Figure $3 b, e)[55,56]$ or embedded in the dense oxide layer (Figure 3c,f) [56]. The incorporation of Ag NPs in the titanium dioxide $\left(\mathrm{TiO}_{2}\right)$ matrix has no effect on the surface morphology of the coatings. All of the layers were porous with well-defined pores ranging in size from a few nanometers up to $5 \mu \mathrm{m}$ [38], which is the typical morphology of MAO. Moreover, the contents of Ag NPs on the surface went up with the increased amount of Ag NPs in the electrolyte. They found that Ag NPs displayed good antibacterial activity against methicillin-resistant Staphylococcus aureus (S. aureus), one of the most problematic pathogens for orthopedic implants, while showing little cytotoxicity to a human osteoblastic cell line with the adjustment of the content of $\mathrm{Ag} \mathrm{NPs}$ on $\mathrm{TiO}_{2} / \mathrm{Ag}$ coating by decreasing the concentration of the $\mathrm{Ag}$ NPs in the electrolyte [74]. However, the coatings prepared by this method are expensive due to the high price of Ag NPs.
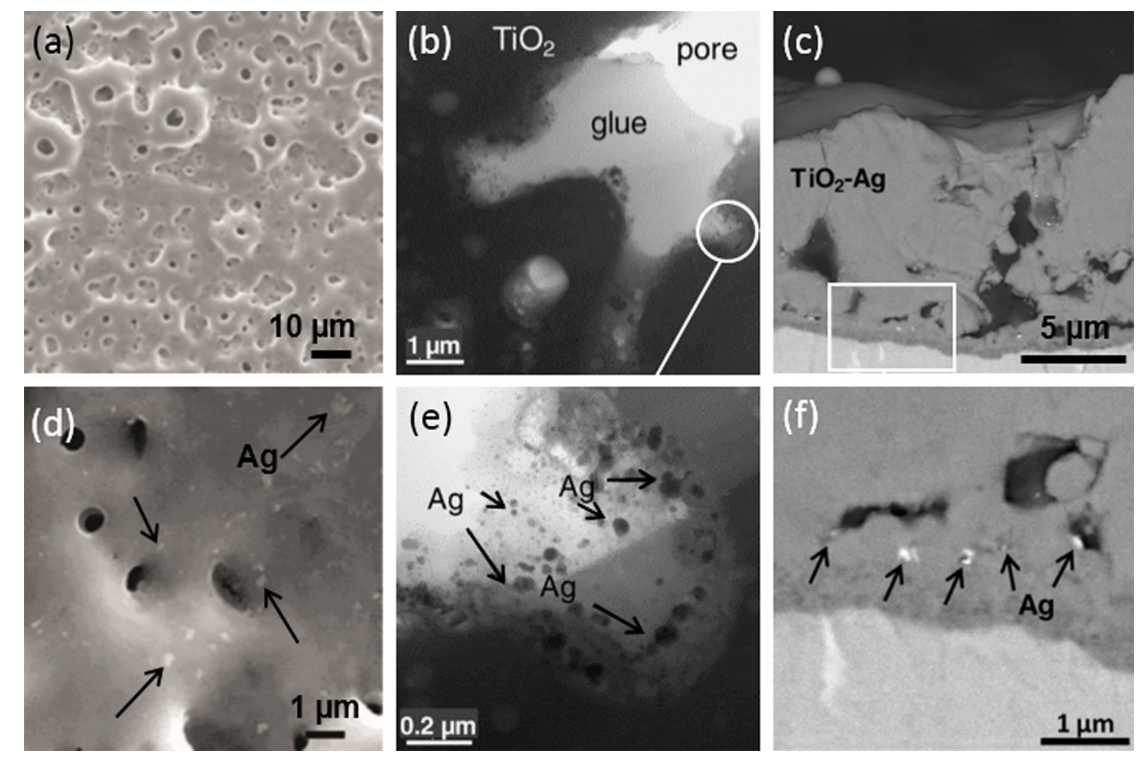

Figure 3. Low and high magnification surface SEM images (a,d); bright field TEM images (b,e), and cross-sectional SEM images (c,f) of the bactericidal coatings showing that the Ag NPs are distributed on the porous surface, in the micropores or embedded in the dense oxide layer. (Reprinted with permission from [38,56]; Copyright 2012 Elsevier, Copyright 2011 Elsevier.) 
$\mathrm{Cu}$ can inactivate the central catabolic and biosynthetic pathways, namely catalytic clusters of dehydratases [75], which endows $\mathrm{Cu}$ with strong antibacterial properties. Yao et al. [57] have prepared $\mathrm{Cu}$-doped $\mathrm{TiO}_{2}$ coatings by $\mathrm{MAO}$ in the working electrolyte containing $\mathrm{NaOH}, \mathrm{NaH}_{2} \mathrm{PO}_{4}$ and $3 \mathrm{~g} \cdot \mathrm{L}^{-1} \mathrm{Cu}$ NPs. The results of top-surface morphologies revealed that $\mathrm{Cu}$ NPs distributed both on the $\mathrm{Cu}$-doped coating surface and inside the pores (Figure 4a). The size of most of the NPs was less than $60 \mathrm{~nm}$. High-resolution XPS spectra indicated that $\mathrm{Cu}$ mainly existed in the $\mathrm{Cu}^{2+}$ (from $\mathrm{CuO}$ ) state (Figure $4 \mathrm{~b}$ ). $\mathrm{Cu}$-doped $\mathrm{TiO}_{2}$ coatings showed excellent antibacterial properties attributed to the incorporation of $\mathrm{Cu}$ NPs with a high surface area to volume ratio, which would directly kill bacteria and release copper ions. A similar mechanism was reported by Raffi et al. [76], in which the reason for the antibacterial property of $\mathrm{Cu}$ NPs was mainly ascribed to the adhesion of Cu NPs onto bacteria surfaces, namely direct contact-killing, since $\mathrm{Cu}$ NPs are oppositely charged with respect to bacteria. When they encounter each other, the reduction reaction will occur at the bacterial cell wall, resulting in the formation of cavities/pits. Though Usman et al. [77] have also testified to the antimicrobial and antifungal activities of $\mathrm{Cu}$-chitosan NPs against methicillin-resistant $S$. aureus, B. subtilis, C. albicans, P. aeruginosa and Salmonella choleraesuis, Pape et al. [78] have confirmed that the antibacterial activity of $\mathrm{Cu}$ NPs was significantly weaker than that of Ag NPs. Moreover, $\mathrm{Cu}$ NPs were rapidly oxidized when exposed to air [79], limiting their application.

With the consideration of the bad dispersion of NPs in solution and the weak adhesion of NPs onto the coating surface, only several valuable studies have been documented in the field of antibacterial NPs by MAO so far.
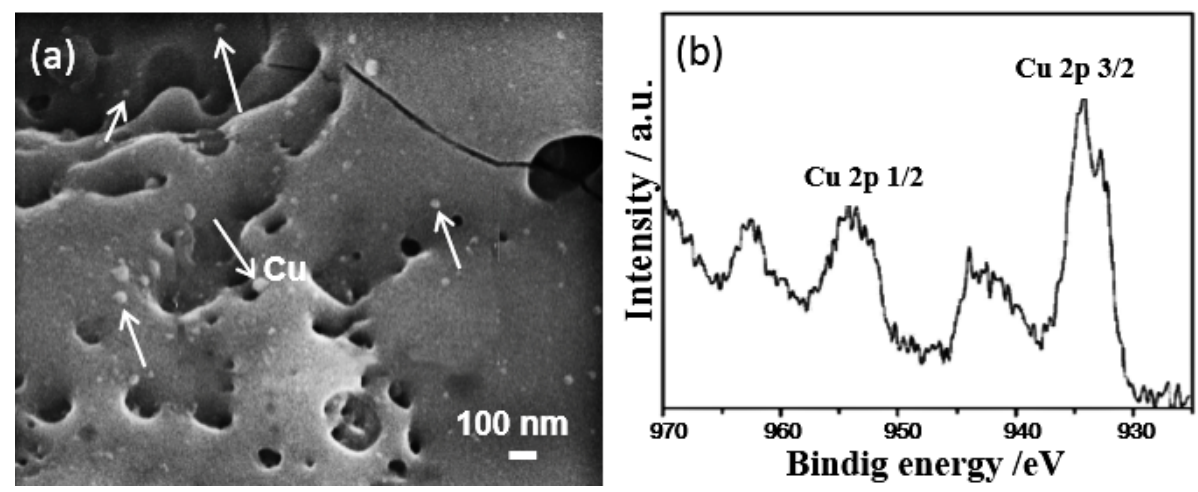

Figure 4. SEM micrographs of $\mathrm{Cu}$-doped coatings revealing the presence of $\mathrm{Cu}$ nanoparticles on the surface and inside the pores (a); high-resolution XPS spectra of $\mathrm{Cu} 2 p$ in $\mathrm{TiO}_{2}$ coating indicated that $\mathrm{Cu}$ mainly exists in the $\mathrm{CuO}$ state (b). (Reprinted with permission from [57]; Copyright 2014 Elsevier.)

\subsection{Introduction of Metallic Compounds into MAO Electrolyte}

For the biomedical industry, it seems to be an attractive strategy to endow implants' surfaces with metallic coatings. Recent studies $[45,80,81]$ have shown that biological or antibacterial elements can be incorporated into the coating during the MAO process by the introduction of metallic compound into the MAO electrolyte. Ag-containing coatings have occupied the largest share of the global antibacterial market.

Song et al. [58] have incorporated Ag into Ti implants by MAO in $0.04 \mathrm{M} \beta$-glycerophosphate disodium salt pentahydrate ( $\beta$-GP), $0.4 \mathrm{MCA}$ and silver nitrate $\left(\mathrm{AgNO}_{3}\right)$ or silver acetate $\left(\mathrm{CH}_{3} \mathrm{COOAg}\right)$ electrolytic solution at a fixed applied voltage range from 250 to $450 \mathrm{~V}$. The addition of $\mathrm{AgNO}_{3}$ reduced the required voltage for the formation of calcium phosphate compounds from 450 down to $400 \mathrm{~V}$ [82,83]. When the concentration of $\mathrm{AgNO}_{3}$ was fixed at $0.004 \mathrm{M}$, the oxidized layer was a porous microstructure with spherical pores at voltages below $350 \mathrm{~V}$ (Figure 5a), while the coating surface became rough and covered with spherical particles and flakes above $380 \mathrm{~V}$ (Figure 5b) due to the existence of calcium phosphate compounds (Figure 5c). MAO coatings containing $0.21-0.45 \mathrm{wt} \%$ of Ag were cytotoxic 
to human osteosarcoma MG63 cells, while Chen et al. [84] reported that $2.05 \mathrm{wt} \%$ Ag displayed no osteoblast cytotoxicity. The comparison results indicated that the cell proliferation not only has a relation to the content of $\mathrm{Ag}$, but also depends on other factors, such as the surface roughness of the coatings [85]. The relatively smooth coating oxidized at $400 \mathrm{~V}$ with a lower content of $\mathrm{Ag}(0.00006 \mathrm{M}$ $\mathrm{AgNO}_{3}$ ) exhibited no cytotoxicity with an unreduced antibacterial property.
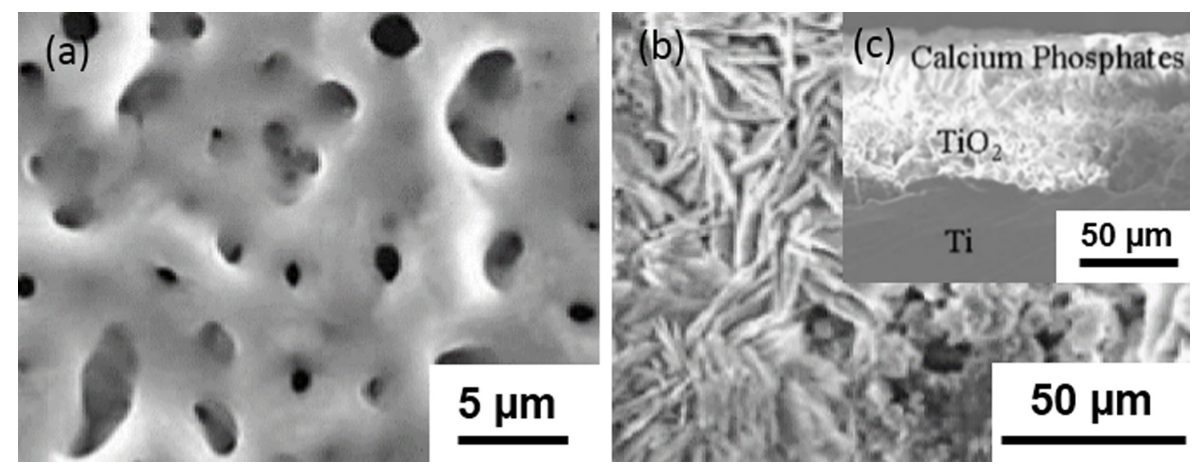

Figure 5. Surface morphologies of MAO samples obtained in electrolyte solution containing $0.004 \mathrm{M}$

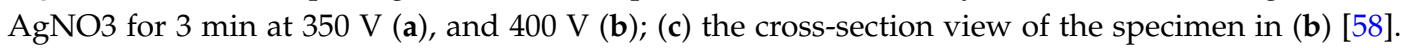
(Reprinted with permission from [58], Copyright 2009 John Wiley \& Sons.)

Muhaffel et al. [59] have also prepared novel multi-layer coatings composed mainly of inner $\mathrm{TiO}_{2}$ layers and outer $\mathrm{HA}\left(\mathrm{HA}\left(\mathrm{Ca}_{10}\left(\mathrm{PO}_{4}\right)_{6}(\mathrm{OH})_{2}\right)\right)$ layers via MAO in $\beta$-GP and CA electrolyte with different addition levels of $\mathrm{AgNO}_{3}\left(0.1 \mathrm{~g} \cdot \mathrm{L}^{-1}\right.$ and $\left.0.4 \mathrm{~g} \cdot \mathrm{L}^{-1}\right)$. Unlike the general surface characteristics of MAO coatings, micro-pores were hardly identified owing to the existence of outer granular HA on MAO-0 (Figure 6a), MAO-0.1 (Figure 6b) or needle-like HA layers on MAO-0.4 (Figure 6c). The addition of $\mathrm{AgNO}_{3}$ can speed up the MAO process at higher current density levels, enhance the crystallinity of the HA layer and precipitation of Ag NPs on the HA layer. Compared to amorphous HA, the crystalline HA exhibits better bioactivity in SBF (simulated body fluid) and biointegration [86]. Ag NPs with a size of 20-30 nm were deposited on the HA layer of MAO-0.1 (Figure 6e) and MAO-0.4 (Figure 6f). The rapid release of $\mathrm{Ag}^{+}$ions at the initial periods and the subsequent slower release contributed to long-term antibacterial activity occurred. Moreover, cumulative release of $\mathrm{Ag}^{+}$ions $(2.5 \mathrm{ppm}$ for MAO-0.1 and 8 ppm for MAO-0.4) was lower than the toxic concentration (10 ppm) of Ag for human cells [87]. Overall consideration, $0.1 \mathrm{~g} \cdot \mathrm{L}^{-1} \mathrm{AgNO}_{3}$ appeared to exhibit sufficient antibacterial activity and no risk of cytotoxicity, while preserving the structural characteristics. Muhaffel et al. [60] have further reported a multi-layer coating consisting of subnatant $\mathrm{TiO}_{2}$ layers and upper bio-mimetic precipitation in disodium hydrogen phosphate $\left(\mathrm{Na}_{2} \mathrm{HPO}_{4}\right), \mathrm{CA}$ and $0.0025 \mathrm{M} \mathrm{CH}_{3} \mathrm{COOAg}$ electrolyte at $380 \mathrm{~V}$. Incorporation of $4.6 \mathrm{wt} \% \mathrm{Ag}$ into the multi-layer led to superior antibacterial efficiency against Escherichia. coli (E. coli) and S. aureus while conserving the biomimetic apatite precipitation. The multilayer consisted of three layers: $\mathrm{A}$ thin compact $\mathrm{TiO}_{2}$ layer above the substrate showing better substrate bonding, a middle porous and thick $\mathrm{TiO}_{2}$ layer on the compact layer and a flake-like top layer of biocompatible compound incorporated with regional Ag particles (Figure 7).

Unlike the common surface micrometer-sized pores of MAO coatings, highly ordered nanopores (Figure 8b,c) within micropits (Figure 8a) were successfully prepared by Chang et al. [61] via a novel one-step high-current anodization (HCA) at the current density of $65 \mathrm{~A} \cdot \mathrm{dm}^{-2}$ in the $\mathrm{AgNO}_{3}$ electrolyte range from $0.5-16 \mathrm{~g} \cdot \mathrm{L}^{-1}$. The nanopore diameter decreased and the wall thickness increased with increasing of $\mathrm{AgNO}_{3}$ concentrations (Figure 8d). Due to the controllable dimensions, the nanoporous structure modulated osteoblast functions, accommodating various clinical needs [88-90]. Scratch tests showed significantly enhanced bonding strength on the HCA treated sample (Figure 8e) in comparison with flaking on the anodized sample (Figure 8f), even at a small normal load. The TEM and XRD showed that $\mathrm{Ag}$ was embedded in crystallized $\mathrm{TiO}_{2}$ in the form of crystallized $\mathrm{AgO}$ NPs with 
diameters between $10 \mathrm{~nm}$ and $30 \mathrm{~nm}$. The crystallized $\mathrm{TiO}_{2}$ also contributed to good bioactivity [49]. Gao et al. [91] reported that several ppb of Ag released quantity were capable of killing all the bacteria. Therefore, the high release level of $\mathrm{Ag}(>200 \mathrm{ppb})$ revealed strong antimicrobial properties, but resulted in severe cytotoxicity. To improve the cytocompatibility and reduce toxicity, $\mathrm{Na}_{3} \mathrm{PO}_{4}$ and $\mathrm{Ca}\left(\mathrm{NO}_{3}\right)_{2}$ were added into the electrolyte to inhibit the formation of nanopores to a certain extent and to lower the release of $\mathrm{Ag}^{+}$while preserving their antibacterial ability.
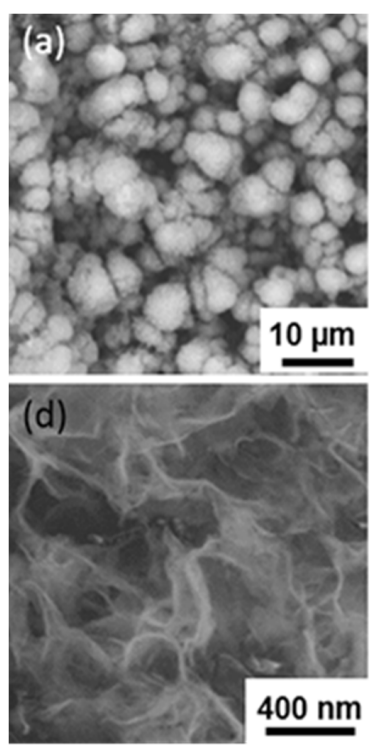
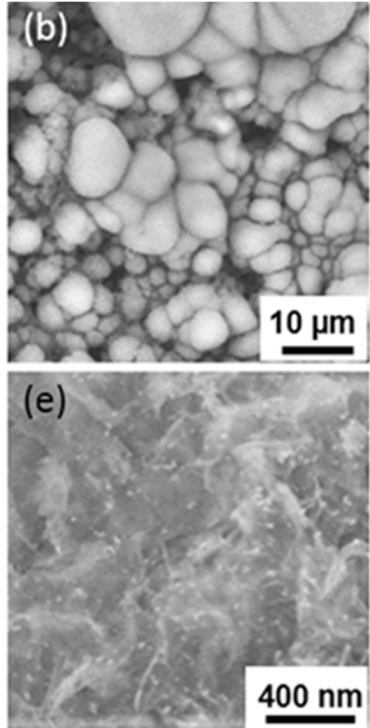
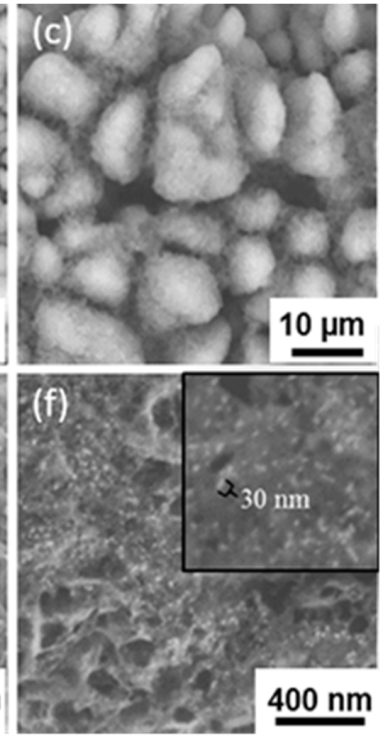

Figure 6. Low and high magnification SEM micrographs of MAO-0 (a,d); MAO-0.1 (b,e) and MAO-0.4 (c,f) [59]. (Reprinted with permission from [59], Copyright 2016 Elsevier.)
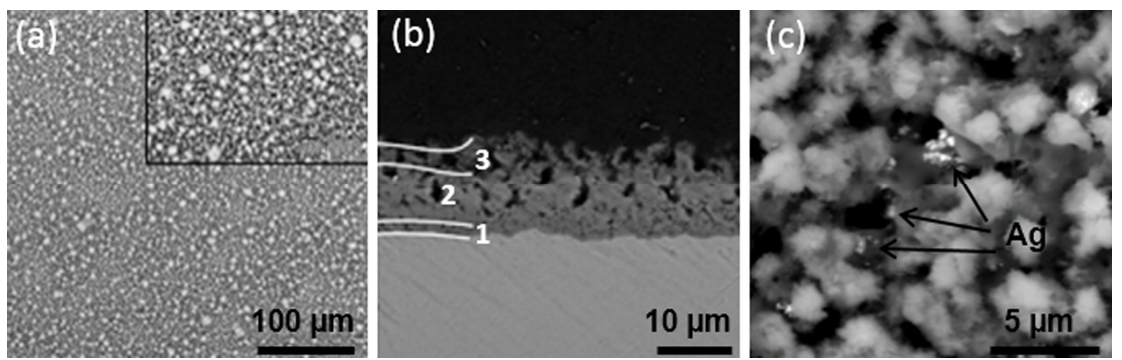

Figure 7. Low magnification surface (a) and cross-sectional SEM (b) micrographs for the MAO-Ag samples obtained in electrolyte solution containing $0.0025 \mathrm{M} \mathrm{CH}_{3} \mathrm{COOAg}$ (1: compact $\mathrm{TiO}_{2}$ layer; 2: porous $\mathrm{TiO}_{2}$ layer; 3: biocompatible compound containing layer); (c) high magnification surface SEM micrographs indicated that regional Ag particles covered the surface [60]. (Reprinted with permission from [60], Copyright 2015 Elsevier.)
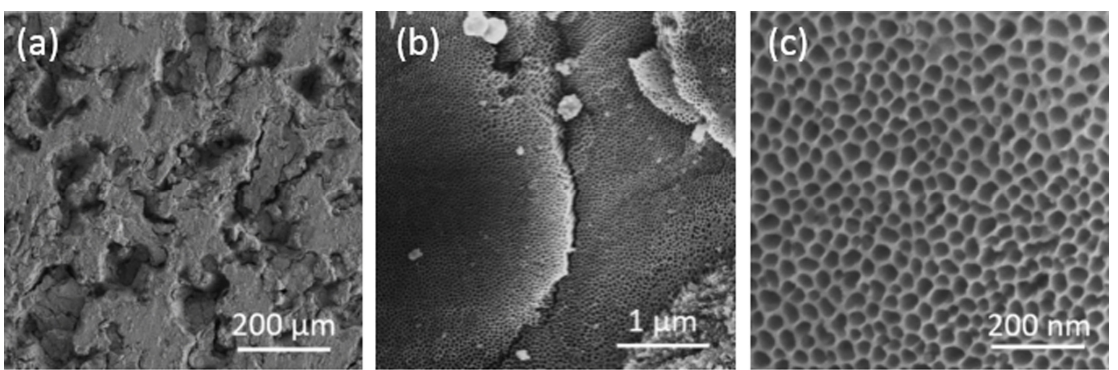

Figure 8. Cont. 


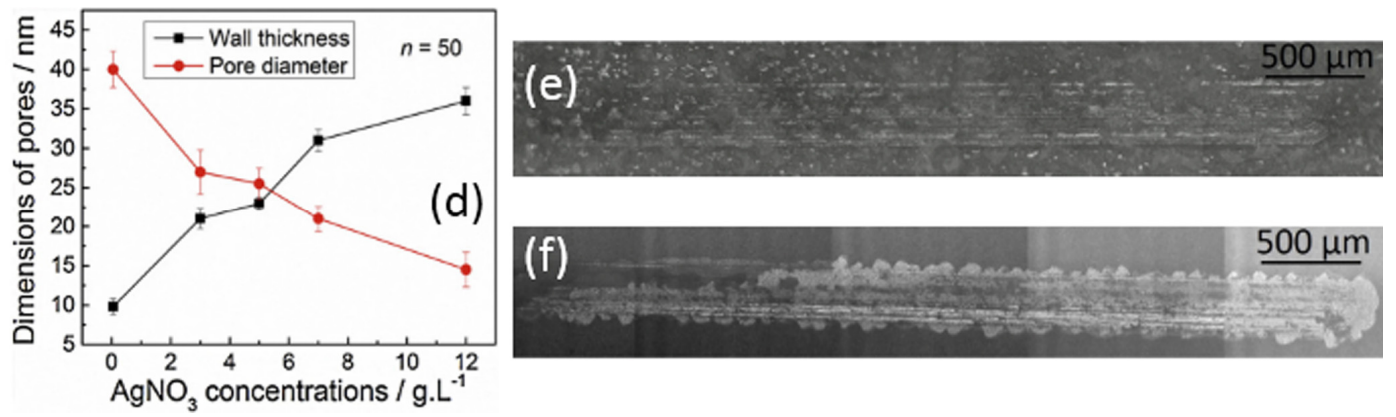

Figure 8. Low-magnification (a) and high-magnification (b,c) SEM images of the high-current anodization (HCA)-treated sample in $\mathrm{AgNO}_{3}$ electrolyte; (d) variation of the pore diameters and thickness of the HCA-treated samples as a function of $\mathrm{AgNO}_{3}$. Scratch SEM images of the sample anodized in the electrolyte with the $\mathrm{AgNO}_{3}$ concentration of $2 \mathrm{~g} \cdot \mathrm{L}^{-1}$ (e) and the sample anodized in ethylene glycol supplemented with $0.5 \mathrm{wt} \% \mathrm{NH}_{4} \mathrm{~F}, 5.0 \mathrm{vol} \% \mathrm{H}_{2} \mathrm{O}$ and $5.0 \mathrm{vol} \% \mathrm{CH}_{3} \mathrm{OH}$ at an applied voltage of $30 \mathrm{~V}$ for $1.5 \mathrm{~h}$ at room temperature (f) showed the significantly enhanced bonding strength on the HCA-treated sample [61]. (Reprinted with permission from [61], Copyright 2015 Elsevier.)

Likewise, a unique structure with a micro-/nano-morphology can also be obtained in $\mathrm{Cu}\left(\mathrm{NO}_{3}\right)_{2}$ electrolyte due to field-assisted chemical etching of $\mathrm{NO}_{3}{ }^{-}$. Huang et al. [62] believed that the use of $\mathrm{Cu}\left(\mathrm{NO}_{3}\right)_{2}$ instead of $\mathrm{AgNO}_{3}$ as the electrolyte may avoid the potential cytotoxicity of heavy metal ions. $\mathrm{Ag}^{+}$was easily oxidized to higher valence $\left(\mathrm{Ag}^{2+}\right)$, which will lead to severe cytotoxicity [61]. However, bivalent $\mathrm{Cu}^{2+}$ in $\mathrm{Cu}\left(\mathrm{NO}_{3}\right)_{2}$ cannot be further oxidized. The results of EDX and XPS confirmed that toxic elements $\mathrm{Cu}$ were not incorporated into the coating surface, so copper will not directly contact the cells to produce cell toxicity. Cross-sectional images (Figure 9) also indicated that highly-ordered nano-channels were perpendicular to the substrate, and a compact layer can be observed between the nanopore arrays and the substrate. Besides, the addition of $\mathrm{PO}_{4}^{3-}$ in the electrolyte further improved the cellular performance [92,93]. Moreover, A well-defined micro-/nano-morphology can also be acquired by this HCA technique in electrolytes, such as $\mathrm{Cu}\left(\mathrm{NO}_{3}\right)_{2}, \mathrm{Zn}\left(\mathrm{NO}_{3}\right)_{2},\left(\mathrm{Na}_{3} \mathrm{PO}_{4}+\mathrm{Ca}\left(\mathrm{NO}_{3}\right)_{2}+\right.$ $\left.\mathrm{Na}_{2} \mathrm{SiO}_{3}\right)$ and $\left(\mathrm{Na}_{3} \mathrm{PO}_{4}+\mathrm{AgNO}_{3}+\mathrm{Na}_{2} \mathrm{SiO}_{3}\right)$, which will extend its application.
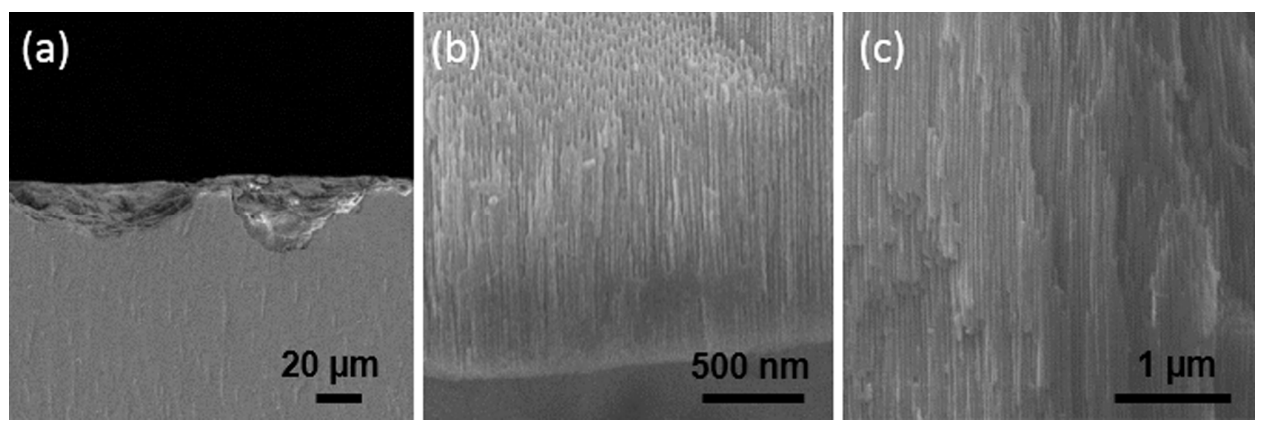

Figure 9. (a) Low and (b,c) high magnification cross-sectional SEM images of the high-current anodization (HCA)-treated sample in $\mathrm{Cu}\left(\mathrm{NO}_{3}\right)_{2}$ electrolyte indicated the presence of highly-ordered nano-channels [62]. (Reprinted with permission from [62], Copyright 2016 Elsevier.)

As an essential trace element for living organisms, $\mathrm{Cu}$ participates in a variety of metabolic activities, so it might be more suitable for antibacterial application compared to Ag. Zhu et al. [63] prepared porous and nano-structured $\mathrm{Cu}$-incorporated $\mathrm{TiO}_{2}$ coatings by $\mathrm{MAO}$ in a novel Cu-containing electrolyte containing $0.05 \mathrm{M} \beta-\mathrm{GP}, 0.1 \mathrm{M} \mathrm{CA}$ and $0.05 \mathrm{M}$ copper acetate $\left(\mathrm{Cu}\left(\mathrm{CH}_{3} \mathrm{COO}\right)_{2}\right)$ at $16.5 \mathrm{~A} \cdot \mathrm{dm}^{-2}$ for $4 \mathrm{~min}$. The result showed that $\mathrm{Cu}-\mathrm{TiO}_{2}$ coatings displayed rough micropores or crater structures with diameters of 3-5 $\mu \mathrm{m}$ (Figure 10a), and the coatings were fully covered with nano-grains with a size of 30-50 nm (Figure 10b) at a higher magnification. The antimicrobial activity 
of $\mathrm{Cu}-\mathrm{TiO}_{2}$ coatings was improved due to the inhibitory effect of $\mathrm{Cu}$. Meanwhile, the osteoblastic adhesion, spreading, early proliferation and late differentiation on $\mathrm{Cu}-\mathrm{TiO}_{2}$ coatings were significantly enhanced due to the existence of the porous nano-structured surface produced during MAO, just like those found by other researchers $[81,94]$. Besides, the $\mathrm{Cu}$ element also plays a vital role in various cell behaviors, including osteoblasts [95], endothelial cells [96], bone marrow stem cells [63] and fibroblasts [64].
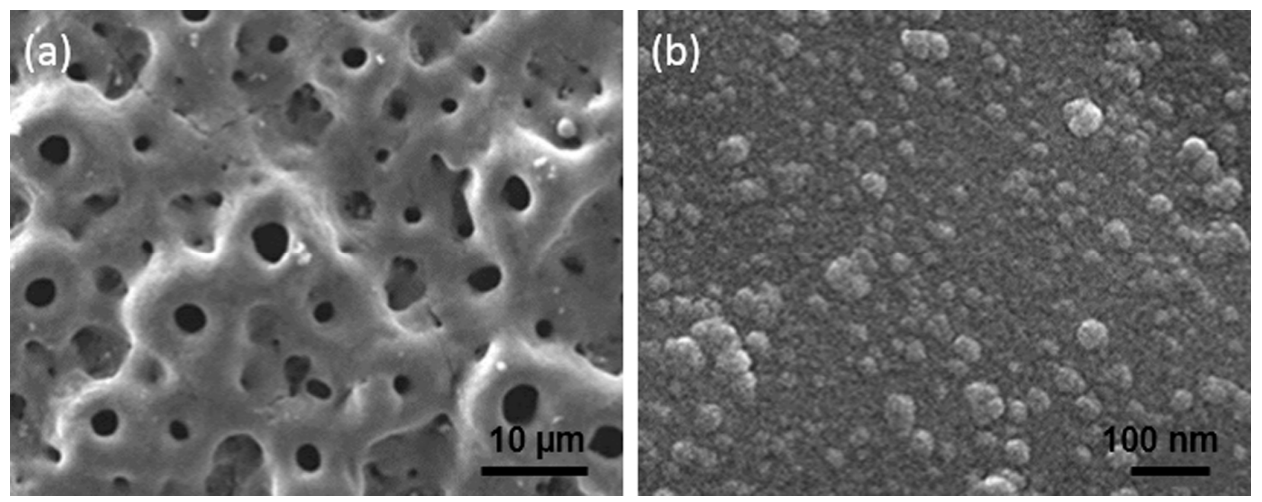

Figure 10. Surface morphologies of $\mathrm{Cu}-\mathrm{TiO}_{2}$ coatings at different magnifications showing micropores with a diameter of 3-5 $\mu \mathrm{m}$ (a) and nano-grains with a size of 30-50 $\mathrm{nm}(\mathbf{b})$ on the surface of $\mathrm{Cu}^{-\mathrm{TiO}_{2}}$ [63]. (Reprinted with permission from [63], Copyright 2013 Elsevier.)

Zhang et al. [64] have investigated the tolerable and safe upper intake level of $\mathrm{Cu}^{2+}$ in order to improve the response of fibroblasts while maintaining the antibacterial activity. $\mathrm{TiO}_{2}$ coatings doped with different amounts of $\mathrm{Cu}^{2+}$ were directly fabricated via MAO in copper acetate $0.02 \mathrm{M}$ $\beta$-GP, $0.2 \mathrm{M} \mathrm{CA}$ and various amounts of $\mathrm{Cu}\left(\mathrm{CH}_{3} \mathrm{COO}\right)_{2}(0.00125 \mathrm{M}, 0.0025 \mathrm{M}, 0.00375 \mathrm{M}$ and $0.005 \mathrm{M})$. As shown in Figure 11a, the coatings still maintained the typical porous structure of $\mathrm{MAO}$, and $\mathrm{Cu}$ content on the surface of the sample increased with the increase of the concentration of $\mathrm{Cu}\left(\mathrm{CH}_{3} \mathrm{COO}\right)_{2}$ in electrolyte. $\mathrm{Cu}$ content also increased gradually from the substrate to the coating surface, and the apparent continuity between the coatings and Ti substrates indicated the strong bonding forces (Figure 11b). As the dose of $\mathrm{Cu}^{2+}$ was increased, the number of adhering bacteria (Figure 11c) was obviously reduced due to the contact-killing and release-killing mechanism, and the bacterial morphologies and membrane integrities were subject to serious disruption (Figure 11d). Results of biological compatibility experiments showed that the appropriate dose of $\mathrm{Cu}(0.67 \mathrm{wt} \%, \mathrm{Cu} 1)$ can improve the adhesion and proliferation of fibroblasts and significantly support denser collagen deposition, while excess $\mathrm{Cu}^{2+}$ was poisonous to the cells (Figure 11e), will disrupt fundamental cellular processes and trigger apoptosis, just as mesenchymal stem cells [97]. Cu1 prepared in $0.00125 \mathrm{M}$ $\mathrm{Cu}\left(\mathrm{CH}_{3} \mathrm{COO}\right)_{2}$ electrolyte with a $\mathrm{Cu}$ mass fraction of 0.67 delivered the best compromise between antibacterial effectiveness and cytotoxicity.

As one of the most important trace elements in the human body, $\mathrm{Zn}$ also has been recognized recently [98], although the antibacterial activity of $\mathrm{Zn}$ is relatively weaker than that of $\mathrm{Ag}$ and $\mathrm{Cu}$. For example, both Zhang et al. [65] and Hu et al. [10] used zinc acetate (ZA) solution to modify a titanium surface by MAO. Zhang et al. [65] prepared $\mathrm{Zn}$-incorporated $\mathrm{TiO}_{2}$ coatings in $0.06 \mathrm{M} \mathrm{ZA \text {, }}$ $0.02 \mathrm{M} \mathrm{CA}$ and $0.15 \mathrm{M}$ Ca-GP solution at a current density of $30 \mathrm{~A} \cdot \mathrm{dm}^{-2}$ for $5 \mathrm{~min}$. Hu et al. [10] obtained $\mathrm{Zn}$-incorporated $\mathrm{TiO}_{2}$ coatings with different $\mathrm{Zn}$ contents $(\mathrm{Z} 0, \mathrm{Z2}, \mathrm{Z} 4, \mathrm{Z} 6)$ in mixture solutions of different concentrations $(0 \mathrm{M}, 0.02 \mathrm{M}, 0.04 \mathrm{M}, 0.06 \mathrm{M})$ of ZA, $0.1 \mathrm{M} \mathrm{CA}$ and $0.05 \mathrm{M} \beta-\mathrm{GP}$ at $16.5 \mathrm{~A} \cdot \mathrm{dm}^{-2}$ for $4 \mathrm{~min}$. It has been found that the incorporation of $\mathrm{Zn}$ in $\mathrm{TiO}_{2}$ did not apparently change the surface topography; all of the $\mathrm{TiO}_{2}$ coatings were still of a typical porous surface morphology, and the micropores with a pore size less than $5 \mu \mathrm{m}$ were uniformly distributed on the coating surface (Figure 12a). The coatings were primarily composed of the anatase and rutile phase. Increasing the 
content of ZA in the electrolyte led to a slight increase in the $\mathrm{Zn}$ content of the oxide layer. However, the feature peaks of $\mathrm{Zn}$-containing compounds were not detected due to the low concentration of $\mathrm{Zn}$ (4.6-9.3 wt \%). The XPS showed that Zn existed in the form of ZnO (Figure 12b). The antibacterial mechanism of $\mathrm{ZnO}$ was attributed to the generation of reactive oxygen species (ROS) [99] on the coating surface with higher Zn content (Figure 12c), rather than the low zinc ions release (<3.62 ppm) [100]. The accumulated released Zn ions not only facilitated the initial adhesion (Figure 12d), spreading and proliferation of bone marrow stem cells (bMSC) [98,101], but also upregulated the gene and protein expression of bMSC while producing no cytotoxicity.

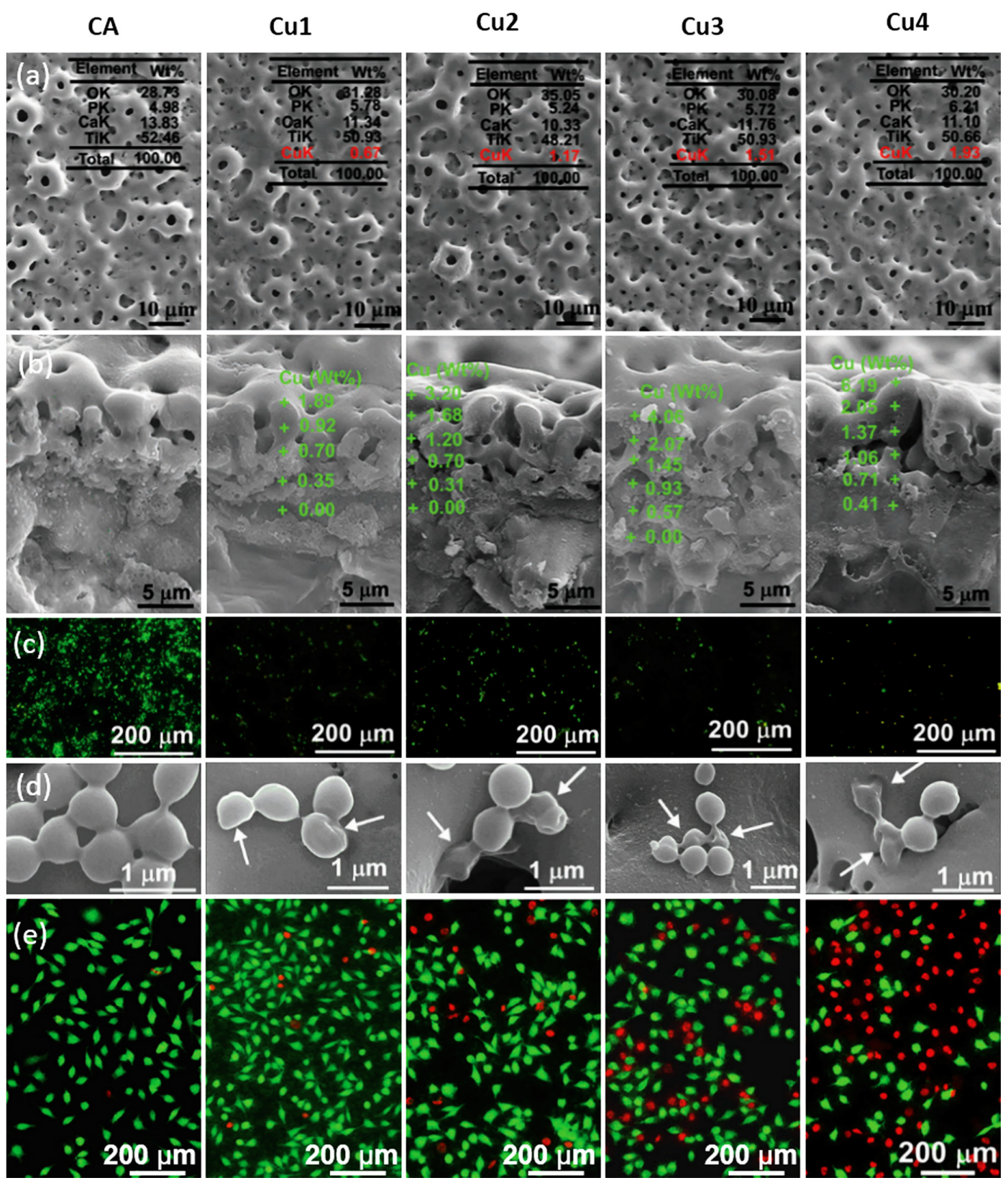

Figure 11. Surface (a) and cross-sectional (b) SEM morphologies images of the CA, Cu1, Cu2, Cu3 and $\mathrm{Cu} 4$ coatings showed that $\mathrm{Cu}$ content increases with the increasing concentration of $\mathrm{Cu}\left(\mathrm{CH}_{3} \mathrm{COO}\right)_{2}$ in electrolyte. Live-dead assay (c), the corresponding bacterial morphologies (d) of S. aureus after $24 \mathrm{~h}$ of incubation and cell viabilities (e) of the cells cultured for three days are highly dependent on the amount of $\mathrm{Cu}$ content incorporated [64]. (Reprinted with permission from [64], Copyright 2016 Royal Society of Chemistry.) 

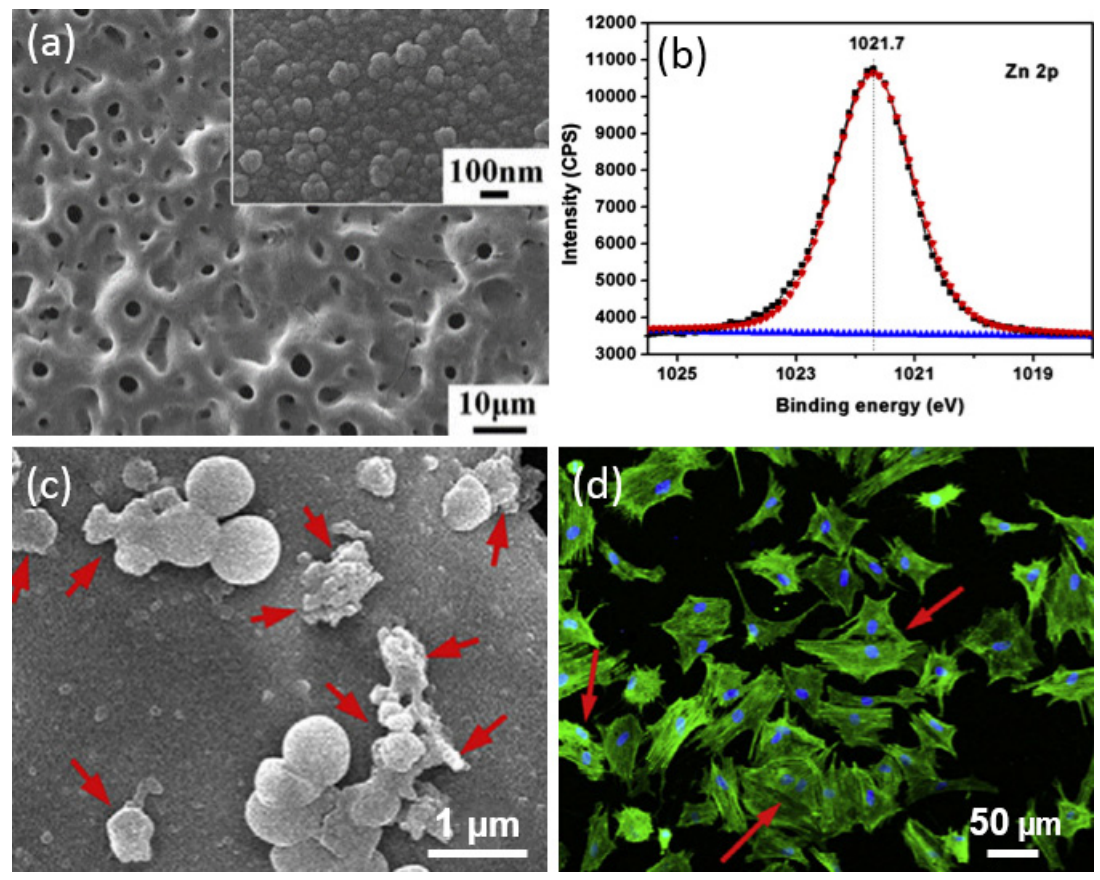

Figure 12. Surface SEM morphologies of Z6 coatings samples obtained in electrolyte solution containing $0.06 \mathrm{M}$ ZA (zinc acetate) (a); high-resolution XPS spectra of Zn $2 p$ in Z6 coating indicated that Zn mainly exists in the $\mathrm{ZnO}$ state (b); the obvious bacterial cell debris and completely lysed cells (indicated by red arrows) showed the improved antimicrobial property of Z6 coatings surfaces (c). The initial adhesion and spreading activity of bMSC cells after $24 \mathrm{~h}$ incubation on Z6 coatings were verified by the extraordinarily stretched cell morphology structure $(\mathbf{d})$ and the presence of mitosis phase cells (indicated by red arrows) [10]. (Reprinted with permission from [10], Copyright 2012 Elsevier.)

\subsection{Introduction of Both Metal Nanoparticles and Metallic Compound into MAO Electrolyte}

Recently, it has found that $\mathrm{Zn}^{2+}$ co-doped with small amount of $\mathrm{Ag}^{+}$may lead to an obvious increase of the antibacterial ability [102] in comparison with single $\mathrm{Zn}^{2+}$. Zhang et al. [66] fabricated micro-porous $\mathrm{TiO}_{2}$ coatings co-doped with $\mathrm{Zn}^{2+}$ and $\mathrm{Ag}$ NPs by MAO in the electrolyte composed of $0.1 \mathrm{M}$ CA, $0.1 \mathrm{M} \mathrm{ZA}, 0.02 \mathrm{M} \beta-\mathrm{GP}, 6 \mathrm{~g} \cdot \mathrm{L}^{-1} \mathrm{Ag} \mathrm{NPs}$ and $0.25 \mathrm{~g} \cdot \mathrm{L}^{-1}$ sodium dodecyl benzene sulfonate for $0.5,1.5,2$ and $4 \mathrm{~min}$. All of the coatings were micro-porous with pore diameters of $1-4 \mu \mathrm{m}$ (Figure 13a), but some deposits were displayed on micro-pores at 4 min (Figure 13b). The contents of $\mathrm{Ag}$ and $\mathrm{Zn}$ on the coating surfaces increased with prolonged MAO time (Figure 13c). Continuity between coating and substrate indicated strong bonding force by $\mathrm{MAO}$, and the Ag and $\mathrm{Zn}$ contents increased gradually from the substrate to the coating surface (Figure 13d). Ag was composed of $73 \%$ $\mathrm{Ag}_{2} \mathrm{O}$ and $27 \%$ metallic $\mathrm{Ag}$ [103,104], while $\mathrm{Zn}$ existed in the form of $\mathrm{ZnO}$ [105]. TEM images indicated that many large rutile or anatase grains of $20-40 \mathrm{~nm}$ in size (Figure 13e,f) and many relatively small Ag nano-grains with sizes of 5-10 nm (Figure 13f) were homogenously embedded in amorphous $\mathrm{TiO}_{2}$ matrix. However, the diffraction spots of $\mathrm{ZnO}$ with trace amounts were not detected. The cumulative ion releases of $\mathrm{Zn}^{2+}(6.88 \mathrm{ppm})$ [10] and $\mathrm{Ag}^{+}(0.684 \mathrm{ppm})$ played an important role in inhibiting the growth of bacteria. Besides, the secondary products such as reactive oxygen species produced by $\mathrm{Zn}^{2+}$ and $\mathrm{Ag}^{+}$were also harmful to bacteria. Carvalho et al. [106] and Jin et al. [28] have also proven the enhanced antibacterial activities of simultaneous incorporation of $\mathrm{Zn}$ and Ag into Ti. Jin et al. [28] believed that the interactions between $\mathrm{Zn}$ ions and bacteria were long-range based on the release of $\mathrm{Zn}$ ions [27], while the interactions between embedded Ag NPs and bacteria were short-range via the micro-galvanic effects without the release of Ag ions [37,107]. Moreover, an appropriate amount of released $\mathrm{Zn}^{2+}$ also accelerated the osteogenic activity of rat bone mesenchymal stem cells (rBMSCs) via the long-range interactions. 

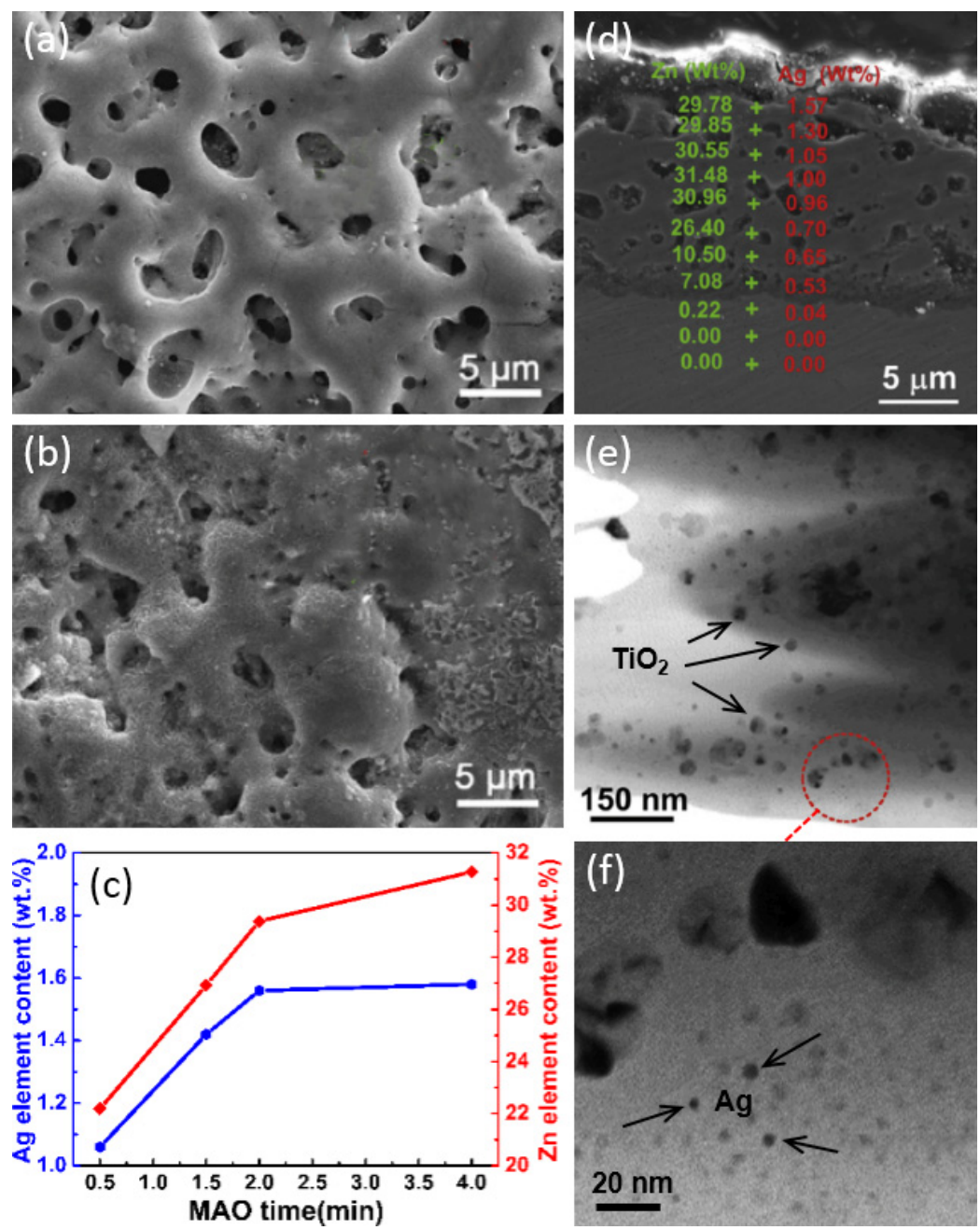

Figure 13. MAO treated coatings at $2 \mathrm{~min}(\mathbf{a})$, and $4 \mathrm{~min}(\mathbf{b})$ showed different surface morphologies in electrolyte solution containing $0.1 \mathrm{M} \mathrm{ZA}$ (zinc acetate), $6 \mathrm{~g} \cdot \mathrm{L}^{-1} \mathrm{Ag}$ NPs. Cross-sectional morphology of the 2 min coating showed that the contents of $\mathrm{Ag}$ and $\mathrm{Zn}$ on the coating surfaces increased with prolonged MAO time (c), and increased gradually from the substrate to the coating surface (d); low (e), and high (f) magnification TEM images showed the $\mathrm{TiO}_{2}$ grains of 20-40 nm in size and nano-grains with a size of 5-10 nm [66]. (Reprinted with permission from [66], Copyright 2016 Elsevier.)

\subsection{MAO Assisted by MS}

MS magnetron sputtering (MS) is a deposition technique belonging to the sputtering processes and is one of the physical vapor deposition (PVD) technologies. The MS deposition process is conducted in an inert gas (usually high-purity argon (Ar) gas) atmosphere regulated by the flow meter in a vacuum chamber. The specimens were placed in the sputtering chamber, and high-purity $\operatorname{Ar}(99.999 \%)$ is introduced when the chamber sputtering is evacuated to a base pressure below $6 \times 10^{-3} \mathrm{~Pa}$. Films are deposited at various sputtering parameters, such as gas flow, working pressure, sputtering power and sputtering time, in order to acquire the desired properties of the material. For the sputtering process, there exists an electric field between the target material and the substrates. Under the action of the electric field, Ar is ionized and bombards the target material located in the cathode of the discharge, which often causes the ejection of ions or atoms from the surface of the target material toward that of the substrates. However, the lower ionization and bombardment rates of Ar often lead to the slower deposition rates and lower film densities. Given this, MS technology is introduced by installing a set of magnets beneath the target. The schematic of the MS deposition system has been described 
in Figure 14. The magnets are used to provide a magnetic field to capture the secondary electrons emitted by the target. Under the action of the magnetic field, secondary electrons are bound in the high density plasma region near the target surface, perform a circular motion around the target surface and constantly impact ionized large amounts of argon ion in the process of movement, thus improving the intensity of Ar ion bombardment and the deposition rate of the films.

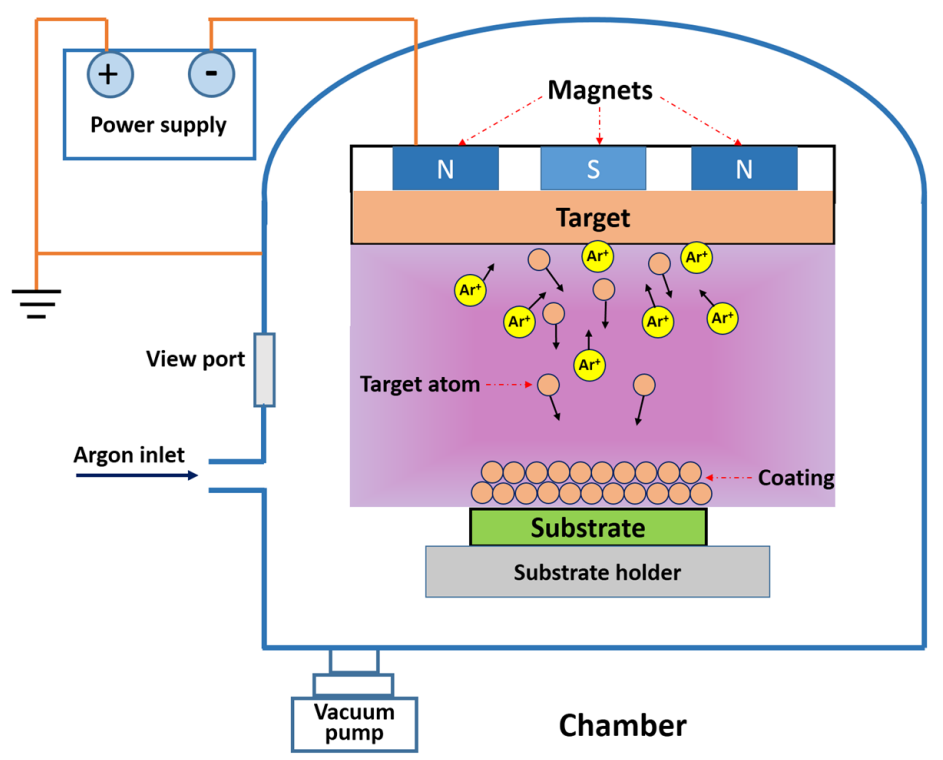

Figure 14. The schematic of the magnetron sputtering (MS) system.

MS is also an effective technique to incorporate antibacterial agents into the implant materials. The desired antibacterial ability can be obtained only by the choice of the optimal processing parameters. Bai et al. [108] have fabricated Ti-Ag composite coatings with different Ag contents (1.2-21.6 at \%) using co-sputtering Ti-Ag targets by MS. The composite coating showed long-term antibacterial ability. However, only the Ag on the surface of Ti-Ag composite coatings contributed to the antibacterial activity [109]. It is hence necessary to carry out a post-treatment to fully use the $\mathrm{Ag}$ on Ti-Ag composite coatings while the antibacterial activity is preserved.

By MS, the deposited AgTi layers cover the entire surface and are firmly combined with the substrate. The concentration of Ag in the layers can be accurately controlled only by adjusting the technological parameters. Though Ag will be dissolved in the electrolyte during the MAO process, a great quantity of $\mathrm{Ag}$ is still reserved in the MAO coating. MAO coating shows a dense inner layer and a rough porous outer structure. The dense inner layer can improve the mechanical interlocking ability and prevent the corrosion from body fluid, while the porous outer structure may increase the surface roughness, thus promoting cell reaction. The desirable antibacterial ability and compatibility can achieve a balance by this duplex technique of combining MS and MAO.

Zhang et al. [110] have developed the novel duplex-treatment technique combining MS with MAO to prepare the Ag-containing bioactive antibacterial coatings. AgTi layers were first deposited onto Ti by MS, then subjected to MAO at $20 \mathrm{~A} \cdot \mathrm{dm}^{-2}$ for 2, 5 and $8 \mathrm{~min}$ in the electrolyte containing $26.4 \mathrm{~g} \cdot \mathrm{L}^{-1} \mathrm{CA}$ and $4.3 \mathrm{~g} \cdot \mathrm{L}^{-1} \beta$-GP. The presence of Ag did not exert a significant influence on the voltage and surface morphology. Micron-sized pores were still distributed over the surfaces, and pore sizes tend to increase (Figure 15a-c) due to the generated larger breakdown channels and more intense sparking with the increase of oxidation time. The coatings were comprised of rutile, anatase and a little Ag. However, Ag was uniformly distributed throughout the coating surface (Figure 15d), but in the form of Ag NPs [56]. During MAO, a large amount of Ag was dissolved in the electrolyte, which caused a sharp decrease in the $\mathrm{Ag}$ content of the MAO coatings. $\mathrm{Ag}$, existing as the metallic $\mathrm{Ag}^{0}$ state, also showed excellent antibacterial ability. 


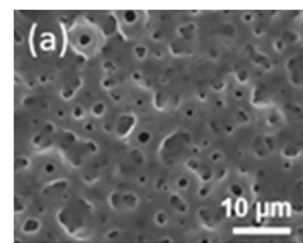

(e)

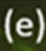

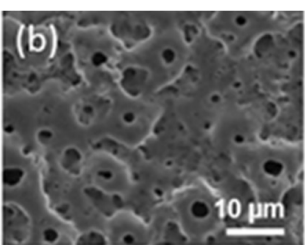

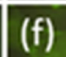

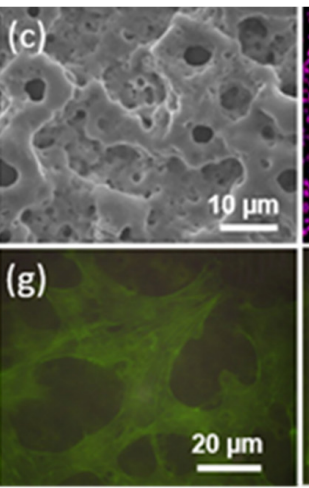

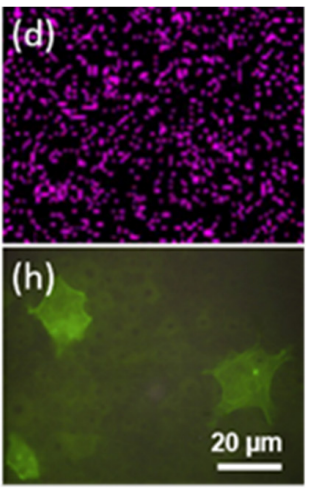

Figure 15. SEM surface micrographs of M-AgTi coating oxidation for $2 \mathrm{~min}(\mathbf{a}), 5 \mathrm{~min}(\mathbf{b})$ and $8 \mathrm{~min}$ (c) indicated that the pore size increase with the increasing oxidation time. EDX maps showed that Ag were uniformly distributed throughout the coating surface (d). Fluorescence microscopy images of F-actin cytoskeleton of pre-osteoblast cells cultured for 48 h on M0 (e), M1 (f), M2 (g) and M3 (h) coatings indicated that a high concentration of Ag exhibited cytotoxic effect [110,111]. (Reprinted with permission from [110,111]; Copyright 2013 Elsevier, Copyright 2014 Elsevier.)

Furthermore, Zhang et al. [111] produced $\mathrm{TiO}_{2}$ coatings with different $\mathrm{Ag}$ concentrations (M0, M1, M2, M3) by the above duplex-treatment technique. The concentration of $\mathrm{Ag}$ in the $\mathrm{TiO}_{2}$ coatings increased with the increase of Ag incorporated in the AgTi layers. The initially high level and subsequently low level of Ag release provided relatively long-term antibacterial activities and met the clinical requirements. Nonetheless, M2 and M3 with 1.36 and 1.93 wt \% (Figure 15g,h) Ag exhibited cytotoxic effect, which restricted cell proliferation and caused cell death. M0 with $0.95 \mathrm{wt} \% \mathrm{Ag}$ (Figure 15f) achieved a balance between antibacterial properties and good pre-osteoblast cell viability.

On this basis, He et al. [112] fabricated porous Ag/Sr-containing $\mathrm{TiO}_{2}$ coatings via a similar method in the MAO electrolyte containing $0.167 \mathrm{M} \mathrm{CA}, 0.02 \mathrm{M} \beta$-GP and $0.033 \mathrm{M}$ strontium acetate hemihydrate (SA). The coating displayed long-lasting antibacterial ability even up to 28 days due to the incorporation of Ag. An addition of the bioactive element $\mathrm{Sr}$ alleviated the potential cytotoxic effect of the excessive Ag and further facilitated the proliferation and differentiation of MC3T3-E1 osteoblasts (Figure 16).
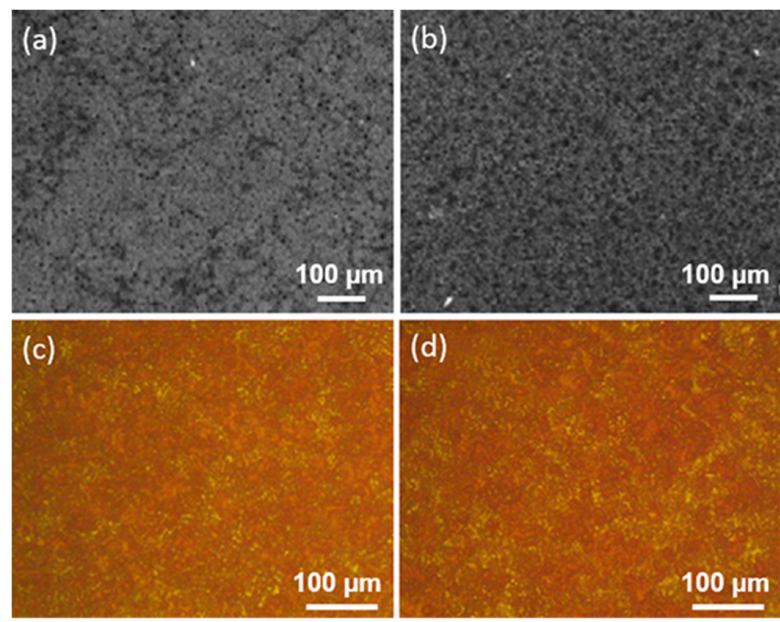

Figure 16. SEM images of MC3T3-E1 cells after culturing for 3 days and quantitative results of collagen secreted by MC3T3-E1 cells after culturing for 7 days on M-Ag0.40 (a,c) and M-Sr/Ag0.40 $(\mathbf{b}, \mathbf{d})$ indicated that the bioactive element $\mathrm{Sr}$ is able to facilitate cell proliferation and differentiation of MC3T3-E1 osteoblasts and alleviate the potential cytotoxic effect of excessive Ag [112]. (Reprinted with permission from [112], Copyright 2016 IOP.) 


\section{Conclusions and Future Outlook}

Implant-associated infections are still one of the critical issues for dental and orthopedic implantology. The surface modification of $\mathrm{Ti}$ and $\mathrm{Ti}$ alloy seems to be a challenging strategy to prevent the development of peri-implant infection. In the present paper, the MAO technique effectively and versatilely introduces inorganic antibacterial metal elements (e.g., Ag, Cu, Zn) into biomedical implants, which successfully solves the growing problem of peri-implant infection. In this mini-review, the research advance in the fabrication of anti-microbial surfaces by MAO is summarized. Antibacterial metal elements were introduced into the electrolyte in the form of either metal NPs or metallic compounds.

However, the main open problems related to this strategy are that the antibacterial effect increases in a dose-dependent manner, but coupled to cytotoxic behavior at a higher concentration. In fact, many Ti-based implants with strong antibacterial properties are still not available in the field of medicine, probably due to the problem mentioned above. In this review, we can also see that many studies have only focused on the development of Ti-based surfaces with an effective antibacterial effect, but ignored the study of bioactivity and toxicity. Therefore, it is necessary to precisely control the content of the antibacterial metal elements and MAO parameters towards an optimal trade-off between antibacterial properties and cytotoxicity. It is a potential way to achieve an enhancement of both the antibacterial property and bioactivity directly by the simultaneous addition of antibacterial metal elements and bioactive elements, such as strontium ( $\mathrm{Sr}$ ) and silicon (Si) in the MAO electrolyte.

In addition, the MAO method combined with MS was introduced to obtain the desired antibacterial property and fabricate bioactive coatings in this review. Ca-P ions can be formed in the porous bio-ceramic layer on the Ti surface by MAO and further transformed into crystal HA through other treatment, such as heat treatment or electrophoretic deposition. The good crystallinity of HA is conducive to cell reaction and bioactivity. Therefore, it is still a trend to develop new methods that can promote the formation of high crystallinity HA.

In conclusion, in order to overcome the toxicity concerns and guarantee the prolonging antibacterial properties, it seems to be a future research trend in the biomaterial field to add antibacterial metal elements and bioactive elements by MAO directly or assisted by other surface modification techniques, such as heat treatment, hydrothermal treatment and plasma spraying, in the near future.

Acknowledgments: This work was supported by the National Natural Science Foundation of China (51671140 and 31400815), the Natural Science Foundation of Shanxi Province (2015021063), the Qualified Personnel Foundation of Taiyuan University of Technology (QPFT) (tyutrc-2011257a) and the Research Project Supported by Shanxi Scholarship Council of China (2013-030 and 2015-034).

Conflicts of Interest: The authors declare no conflict of interest.

\section{References}

1. Wang, K. The use of titanium for medical applications in the USA. Mater. Sci. Eng. C 1996, A213, $134-137$. [CrossRef]

2. Liu, X.; Chu, P.; Ding, C. Surface modification of titanium, titanium alloys, and related materials for biomedical applications. Mater. Sci. Eng. R Rep. 2004, 47, 49-121. [CrossRef]

3. Pohrelyuk, I.; Yaskiv, O.; Tkachuk, O.; Lee, D.B. Formation of oxynitride layers on titanium alloys by gas diffusion treatment. Met. Mater. Int. 2009, 15, 949-953. [CrossRef]

4. Glinel, K.; Thebault, P.; Humblot, V.; Pradier, C.M.; Jouenne, T. Antibacterial surfaces developed from bio-inspired approaches. Acta Biomater. 2012, 8, 1670-1684. [CrossRef] [PubMed]

5. Zhao, L.; Wang, H.; Huo, K.; Cui, L.; Zhang, W.; Ni, H.; Zhang, Y.; Wu, Z.; Chu, P.K. Antibacterial nano-structured titania coating incorporated with silver nanoparticles. Biomaterials 2011, 32, 5706-5716. [CrossRef] [PubMed]

6. Donlan, R.M.; Costerton, J.W. Biofilms: Survival mechanisms of clinically relevant microorganisms. Clin. Microbiol. Rev. 2002, 15, 167-193. [CrossRef] [PubMed]

7. Stewart, P.S.; Costerton, J.W. Antibiotic resistance of bacteria in biofilms. Lancet 2001, 358, 135-138. [CrossRef] 
8. Huang, R.; Han, Y.; Lu, S. Enhanced osteoblast functions and bactericidal effect of Ca and Ag dual-ion implanted surface layers on nanograined titanium alloys. J. Mater. Chem. B 2014, 2, 4531-4543. [CrossRef]

9. Hetrick, E.M.; Schoenfisch, M.H. Reducing implant-related infections: Active release strategies. Chem. Soc. Rev. 2006, 35, 780-789. [CrossRef] [PubMed]

10. Hu, H.; Zhang, W.; Qiao, Y.; Jiang, X.; Liu, X.; Ding, C. Antibacterial activity and increased bone marrow stem cell functions of $\mathrm{Zn}$-incorporated $\mathrm{TiO}_{2}$ coatings on titanium. Acta Biomater. 2012, 8, 904-915. [CrossRef] [PubMed]

11. Esposito, S.; Leone, S. Prosthetic joint infections: Microbiology, diagnosis, management and prevention. Int. J. Antimicrob. Agents 2008, 32, 287-293. [CrossRef] [PubMed]

12. Zimmerli, W. Infection and musculoskeletal conditions: Prosthetic-joint-associated infections. Best Pract. Res. Clin. Rheumatol. 2006, 20, 1045-1063. [CrossRef] [PubMed]

13. Tsai, M.T.; Chang, Y.Y.; Huang, H.L.; Hsu, J.T.; Chen, Y.C.; Wu, A.Y.J. Characterization and antibacterial performance of bioactive Ti-Zn-O coatings deposited on titanium implants. Thin Solid Films 2013, 528, 143-150. [CrossRef]

14. Bai, X.; Sandukas, S.; Appleford, M.; Ong, J.L.; Rabiei, A. Antibacterial effect and cytotoxicity of Ag-doped functionally graded hydroxyapatite coatings. J Biomed. Mater. Res. B Appl. Biomater. 2012, 100, 553-561. [CrossRef] [PubMed]

15. Lim, P.N.; Teo, E.Y.; Ho, B.; Tay, B.Y.; Thian, E.S. Effect of silver content on the antibacterial and bioactive properties of silver-substituted hydroxyapatite. J Biomed. Mater. Res. A 2013, 101, 2456-2464. [CrossRef] [PubMed]

16. Mai, L.; Wang, D.; Zhang, S.; Xie, Y.; Huang, C.; Zhang, Z. Synthesis and bactericidal ability of $\mathrm{Ag} / \mathrm{TiO} 2$ composite films deposited on titanium plate. Appl. Surf. Sci. 2010, 257, 974-978. [CrossRef]

17. Chen, L.; Zheng, L.; Lv, Y.; Liu, H.; Wang, G.; Ren, N.; Liu, D.; Wang, J.; Boughton, R.I. Chemical assembly of silver nanoparticles on stainless steel for antimicrobial applications. Surf. Coat. Technol. 2010, 204, 3871-3875. [CrossRef]

18. Alarcon, E.I.; Udekwu, K.; Skog, M.; Pacioni, N.L.; Stamplecoskie, K.G.; Gonzalez-Bejar, M.; Polisetti, N.; Wickham, A.; Richter-Dahlfors, A.; Griffith, M.; et al. The biocompatibility and antibacterial properties of collagen-stabilized, photochemically prepared silver nanoparticles. Biomaterials 2012, 33, 4947-4956. [CrossRef] [PubMed]

19. Jia, Z.; Xiu, P.; Li, M.; Xu, X.; Shi, Y.; Cheng, Y.; Wei, S.; Zheng, Y.; Xi, T.; Cai, H.; et al. Bioinspired anchoring agnps onto micro-nanoporous $\mathrm{TiO}_{2}$ orthopedic coatings: Trap-killing of bacteria, surface-regulated osteoblast functions and host responses. Biomaterials 2016, 75, 203-222. [CrossRef] [PubMed]

20. Mei, S.; Wang, H.; Wang, W.; Tong, L.; Pan, H.; Ruan, C.; Ma, Q.; Liu, M.; Yang, H.; Zhang, L.; et al. Antibacterial effects and biocompatibility of titanium surfaces with graded silver incorporation in titania nanotubes. Biomaterials 2014, 35, 4255-4265. [CrossRef] [PubMed]

21. Reithofer, M.R.; Lakshmanan, A.; Ping, A.T.; Chin, J.M.; Hauser, C.A. In situ synthesis of size-controlled, stable silver nanoparticles within ultrashort peptide hydrogels and their anti-bacterial properties. Biomaterials 2014, 35, 7535-7542. [CrossRef] [PubMed]

22. Wang, Y.; Ding, X.; Chen, Y.; Guo, M.; Zhang, Y.; Guo, X.; Gu, H. Antibiotic-loaded, silver core-embedded mesoporous silica nanovehicles as a synergistic antibacterial agent for the treatment of drug-resistant infections. Biomaterials 2016, 101, 207-216. [CrossRef] [PubMed]

23. Wu, H.; Zhang, X.; He, X.; Li, M.; Huang, X.; Hang, R.; Tang, B. Wear and corrosion resistance of anti-bacterial Ti-Cu-N coatings on titanium implants. Appl. Surf. Sci. 2014, 317, 614-621. [CrossRef]

24. Zhang, X.; Huang, X.; Jiang, L.; Ma, Y.; Fan, A.; Tang, B. Surface microstructures and antimicrobial properties of copper plasma alloyed stainless steel. Appl. Surf. Sci. 2011, 258, 1399-1404. [CrossRef]

25. Zhang, X.; Huang, X.; Ma, Y.; Lin, N.; Fan, A.; Tang, B. Bactericidal behavior of cu-containing stainless steel surfaces. Appl. Surf. Sci. 2012, 258, 10058-10063. [CrossRef]

26. Zhang, X.; Ma, Y.; Lin, N.; Huang, X.; Hang, R.; Fan, A.; Tang, B. Microstructure, antibacterial properties and wear resistance of plasma Cu-Ni surface modified titanium. Surf. Coat. Technol. 2013, 232, 515-520. [CrossRef]

27. Huo, K.; Zhang, X.; Wang, H.; Zhao, L.; Liu, X.; Chu, P.K. Osteogenic activity and antibacterial effects on titanium surfaces modified with Zn-incorporated nanotube arrays. Biomaterials 2013, 34, 3467-3478. [CrossRef] [PubMed] 
28. Jin, G.; Qin, H.; Cao, H.; Qian, S.; Zhao, Y.; Peng, X.; Zhang, X.; Liu, X.; Chu, P.K. Synergistic effects of dual $\mathrm{Zn} / \mathrm{Ag}$ ion implantation in osteogenic activity and antibacterial ability of titanium. Biomaterials 2014, 35, 7699-7713. [CrossRef] [PubMed]

29. Jin, G.; Qin, H.; Cao, H.; Qiao, Y.; Zhao, Y.; Peng, X.; Zhang, X.; Liu, X.; Chu, P.K. Zn/Ag micro-galvanic couples formed on titanium and osseointegration effects in the presence of $S$. Aureus. Biomaterials 2015, 65, 22-31. [CrossRef] [PubMed]

30. Dastjerdi, R.; Montazer, M. A review on the application of inorganic nano-structured materials in the modification of textiles: Focus on anti-microbial properties. Colloids Surf. B Biointerfaces 2010, 79, 5-18. [CrossRef] [PubMed]

31. He, X.; Li, M.; Wang, H.; Zhang, X.; Tang, B.I.N. Preparation of copper and chromium alloyed layers on pure titanium by plasma surface alloying technology. Surf. Rev. Lett. 2015, 22, 1550056. [CrossRef]

32. Dizaj, S.M.; Lotfipour, F.; Barzegar-Jalali, M.; Zarrintan, M.H.; Adibkia, K. Antimicrobial activity of the metals and metal oxide nanoparticles. Mater. Sci. Eng. C Mater. Biol. Appl. 2014, 44, 278-284. [CrossRef] [PubMed]

33. Rai, M.; Yadav, A.; Gade, A. Silver nanoparticles as a new generation of antimicrobials. Biotechnol. Adv. 2009, 27, 76-83. [CrossRef] [PubMed]

34. Ferraris, S.; Spriano, S. Antibacterial titanium surfaces for medical implants. Mater. Sci. Eng. C Mater. Biol. Appl. 2016, 61, 965-978. [CrossRef] [PubMed]

35. Wan, Y.Z.; Raman, S.; He, F.; Huang, Y. Surface modification of medical metals by ion implantation of silver and copper. Vacuum 2007, 81, 1114-1118. [CrossRef]

36. Wan, Y.Z.; Xiong, G.Y.; Liang, H.; Raman, S.; He, F.; Huang, Y. Modification of medical metals by ion implantation of copper. Appl. Surf. Sci. 2007, 253, 9426-9429. [CrossRef]

37. Cao, H.; Qiao, Y.; Liu, X.; Lu, T.; Cui, T.; Meng, F.; Chu, P.K. Electron storage mediated dark antibacterial action of bound silver nanoparticles: Smaller is not always better. Acta Biomater. 2013, 9, 5100-5110. [CrossRef] [PubMed]

38. Necula, B.S.; van Leeuwen, J.P.T.M.; Fratila-Apachitei, L.E.; Zaat, S.A.J.; Apachitei, I.; Duszczyk, J. In vitro cytotoxicity evaluation of porous $\mathrm{TiO}_{2}-\mathrm{Ag}$ antibacterial coatings for human fetal osteoblasts. Acta Biomater. 2012, 8, 4191-4197. [CrossRef] [PubMed]

39. Lee, S.-B.; Otgonbayar, U.; Lee, J.-H.; Kim, K.-M.; Kim, K.-N. Silver ion-exchanged sodium titanate and resulting effect on antibacterial efficacy. Surf. Coat. Technol. 2010, 205, S172-S176. [CrossRef]

40. García-Serrano, J.; Gómez-Hernández, E.; Ocampo-Fernández, M.; Pal, U. Effect of Ag doping on the crystallization and phase transition of $\mathrm{TiO}_{2}$ nanoparticles. Curr. Appl. Phys. 2009, 9, 1097-1105. [CrossRef]

41. Meng, F.; Sun, Z. A mechanism for enhanced hydrophilicity of silver nanoparticles modified $\mathrm{TiO}_{2}$ thin films deposited by RF magnetron sputtering. Appl. Surf. Sci. 2009, 255, 6715-6720. [CrossRef]

42. Tian, X.B.; Wang, Z.M.; Yang, S.Q.; Luo, Z.J.; Fu, R.K.Y.; Chu, P.K. Antibacterial copper-containing titanium nitride films produced by dual magnetron sputtering. Surf. Coat. Technol. 2007, 201, 8606-8609. [CrossRef]

43. Li, B.; Liu, X.; Meng, F.; Chang, J.; Ding, C. Preparation and antibacterial properties of plasma sprayed nano-titania/silver coatings. Mater. Chem. Phys. 2009, 118, 99-104. [CrossRef]

44. Mungkalasiri, J.; Bedel, L.; Emieux, F.; Doré, J.; Renaud, F.N.R.; Maury, F. Dli-CVD of TiO $2-C u$ antibacterial thin films: Growth and characterization. Surf. Coat. Technol. 2009, 204, 887-892. [CrossRef]

45. Sul, Y.T.; Kang, B.S.; Johansson, C.; Um, H.S.; Park, C.J.; Albrektsson, T. The roles of surface chemistry and topography in the strength and rate of osseointegration of titanium implants in bone. J. Biomed. Mater. Res. A 2009, 89, 942-950. [CrossRef] [PubMed]

46. Wei, D.; Zhou, Y.; Yang, C. Structure, cell response and biomimetic apatite induction of gradient $\mathrm{TiO}_{2}$-based/nano-scale hydrophilic amorphous titanium oxide containing ca composite coatings before and after crystallization. Colloids Surf. B Biointerfaces 2009, 74, 230-237. [CrossRef] [PubMed]

47. Yan, J.; Sun, J.F.; Chu, P.K.; Han, Y.; Zhang, Y.M. Bone integration capability of a series of strontium-containing hydroxyapatite coatings formed by micro-arc oxidation. J Biomed. Mater. Res. A 2013, 101, 2465-2480. [CrossRef] [PubMed]

48. Zhao, B.H.; Lee, I.S.; Han, I.H.; Park, J.C.; Chung, S.M. Effects of surface morphology on human osteosarcoma cell response. Curr. Appl. Phys. 2007, 7, e6-e10. [CrossRef]

49. Sun, J.; Han, Y.; Cui, K. Microstructure and apatite-forming ability of the mao-treated porous titanium. Surf. Coat. Technol. 2008, 202, 4248-4256. [CrossRef] 
50. Miao, S.; Cheng, K.; Weng, W.; Du, P.; Shen, G.; Han, G.; Yan, W.; Zhang, S. Fabrication and evaluation of $\mathrm{Zn}$ containing fluoridated hydroxyapatite layer with zn release ability. Acta Biomater. 2008, 4, 441-446. [CrossRef] [PubMed]

51. Wang, Y.; Yu, H.; Chen, C.; Zhao, Z. Review of the biocompatibility of micro-arc oxidation coated titanium alloys. Mater. Des. 2015, 85, 640-652. [CrossRef]

52. Matykina, E.; Arrabal, R.; Skeldon, P.; Thompson, G.E. Transmission electron microscopy of coatings formed by plasma electrolytic oxidation of titanium. Acta Biomater. 2009, 5, 1356-1366. [CrossRef] [PubMed]

53. Wan, L.; Li, J.F.; Feng, J.Y.; Sun, W.; Mao, Z.Q. Anatase $\mathrm{TiO}_{2}$ films with $2.2 \mathrm{eV}$ band gap prepared by micro-arc oxidation. Mater. Sci. Eng. B 2007, 139, 216-220. [CrossRef]

54. Cheng, Y.L.; Wu, X.Q.; Xue, Z.G.; Matykina, E.; Skeldon, P.; Thompson, G.E. Microstructure, corrosion and wear performance of plasma electrolytic oxidation coatings formed on Ti-6Al-4V alloy in silicate-hexametaphosphate electrolyte. Surf. Coat. Technol. 2013, 217, 129-139. [CrossRef]

55. Necula, B.S.; Fratila-Apachitei, L.E.; Zaat, S.A.; Apachitei, I.; Duszczyk, J. In vitro antibacterial activity of porous $\mathrm{TiO}_{2}$-Ag composite layers against methicillin-resistant staphylococcus aureus. Acta Biomater. 2009, 5, 3573-3580. [CrossRef] [PubMed]

56. Necula, B.S.; Apachitei, I.; Tichelaar, F.D.; Fratila-Apachitei, L.E.; Duszczyk, J. An electron microscopical study on the growth of $\mathrm{TiO}_{2}-\mathrm{Ag}$ antibacterial coatings on Ti6Al7Nb biomedical alloy. Acta Biomater. 2011, 7 , 2751-2757. [CrossRef] [PubMed]

57. Yao, X.; Zhang, X.; Wu, H.; Tian, L.; Ma, Y.; Tang, B. Microstructure and antibacterial properties of Cu-doped $\mathrm{TiO}_{2}$ coating on titanium by micro-arc oxidation. Appl. Surf. Sci. 2014, 292, 944-947. [CrossRef]

58. Song, W.H.; Ryu, H.S.; Hong, S.H. Antibacterial properties of Ag (or Pt)-containing calcium phosphate coatings formed by micro-arc oxidation. J. Biomed. Mater. Res. A 2009, 88, 246-254. [CrossRef] [PubMed]

59. Muhaffel, F.; Cempura, G.; Menekse, M.; Czyrska-Filemonowicz, A.; Karaguler, N.; Cimenoglu, H. Characteristics of multi-layer coatings synthesized on Ti6Al4V alloy by micro-arc oxidation in silver nitrate added electrolytes. Surf. Coat. Technol. 2016, 307, 308-315. [CrossRef]

60. Teker, D.; Muhaffel, F.; Menekse, M.; Karaguler, N.G.; Baydogan, M.; Cimenoglu, H. Characteristics of multi-layer coating formed on commercially pure titanium for biomedical applications. Mater. Sci. Eng. C Mater. Biol. Appl. 2015, 48, 579-585. [CrossRef] [PubMed]

61. Chang, C.; Huang, X.; Liu, Y.; Bai, L.; Yang, X.; Hang, R.; Tang, B.; Chu, P.K. High-current anodization: A novel strategy to functionalize titanium-based biomaterials. Electrochim. Acta 2015, 173, 345-353. [CrossRef]

62. Huang, X.; Liu, Y.; Yu, H.; Yang, X.; Wang, Y.; Hang, R.; Tang, B. One-step fabrication of cytocompatible micro/nano-textured surface with $\mathrm{TiO}_{2}$ mesoporous arrays on titanium by high current anodization. Electrochim. Acta 2016, 199, 116-125. [CrossRef]

63. Zhu, W.; Zhang, Z.; Gu, B.; Sun, J.; Zhu, L. Biological activity and antibacterial property of nano-structured $\mathrm{TiO}_{2}$ coating incorporated with $\mathrm{Cu}$ prepared by micro-arc oxidation. J. Mater. Sci. Technol. 2013, 29, $237-244$. [CrossRef]

64. Zhang, L.; Guo, J.; Huang, X.; Zhang, Y.; Han, Y. The dual function of Cu-doped $\mathrm{TiO}_{2}$ coatings on titanium for application in percutaneous implants. J. Mater. Chem. B 2016, 4, 3788-3800. [CrossRef]

65. Zhang, X.; Wang, H.; Li, J.; He, X.; Hang, R.; Huang, X.; Tian, L.; Tang, B. Corrosion behavior of Zn-incorporated antibacterial $\mathrm{TiO}_{2}$ porous coating on titanium. Ceram. Int. 2016, 42, 17095-17100. [CrossRef]

66. Zhang, L.; Gao, Q.; Han, Y. Zn and Ag co-doped anti-microbial $\mathrm{TiO}_{2}$ coatings on Ti by micro-arc oxidation. J. Mater. Sci. Technol. 2016, 32, 919-924. [CrossRef]

67. Yeo, S.Y.; Jeong, S.H. Preparation and characterization of polypropylene/silver nanocomposite fibers. Polym. Int. 2003, 52, 1053-1057. [CrossRef]

68. Zinjarde, S. Bio-inspired nanomaterials and their applications as antimicrobial agents. Chron. Young Sci. 2012, 3, 74-81. [CrossRef]

69. Sondi, I.; Salopek-Sondi, B. Silver nanoparticles as antimicrobial agent: A case study on E. Coli as a model for gram-negative bacteria. J. Colloid Interface Sci. 2004, 275, 177-182. [CrossRef] [PubMed]

70. Yun, H.; Kim, J.D.; Choi, H.C.; Lee, C.W. Antibacterial activity of CNT-Ag and Go-Ag nanocomposites against gram-negative and gram-positive bacteria. B Korean Chem. Soc. 2013, 34, 3261-3264. [CrossRef]

71. Iavicoli, I.; Fontana, L.; Leso, V.; Bergamaschi, A. The effects of nanomaterials as endocrine disruptors. Int. J. Mol. Sci. 2013, 14, 16732-16801. [CrossRef] [PubMed] 
72. Morones, J.R.; Elechiguerra, J.L.; Camacho, A.; Holt, K.; Kouri, J.B.; Ramirez, J.T.; Yacaman, M.J. The bactericidal effect of silver nanoparticles. Nanotechnology 2005, 16, 2346-2353. [CrossRef] [PubMed]

73. Jo, Y.K.; Kim, B.H.; Jung, G. Antifungal activity of silver ions and nanoparticles on phytopathogenic fungi. Plant Dis. 2009, 93, 1037-1043. [CrossRef]

74. Cao, H.; Liu, X. Activating titanium oxide coatings for orthopedic implants. Surf. Coat. Technol. 2013, 233, 57-64. [CrossRef]

75. Macomber, L.; Imlay, J.A. The iron-sulfur clusters of dehydratases are primary intracellular targets of copper toxicity. Proc. Natl. Acad. Sci. USA 2009, 106, 8344-8349. [CrossRef] [PubMed]

76. Raffi, S.M.; Bhatti, T.M.; Akhter, J.I.; Hameed, A.; Yawar, W.; Hasan, M.M. Investigations into the antibacterial behavior of copper nanoparticles against escherichia coli. Ann. Microbiol. 2010, 60, 75-80. [CrossRef]

77. Usman, M.S.; El Zowalaty, M.E.; Shameli, K.; Zainuddin, N.; Salama, M.; Ibrahim, N.A. Synthesis, characterization, and antimicrobial properties of copper nanoparticles. Int. J. Nanomed. 2013, 8, 4467-4479. [PubMed]

78. Le Pape, H.; Solano-Serena, F.; Contini, P.; Devillers, C.; Maftah, A.; Leprat, P. Evaluation of the anti-microbial properties of an activated carbon fibre supporting silver using a dynamic method. Carbon 2002, 40, 2947-2954. [CrossRef]

79. Mahapatra, O.; Bhagat, M.; Gopalakrishnan, C.; Arunachalam, K.D. Ultrafine dispersed CuO nanoparticles and their antibacterial activity. J. Exp. Nanosci. 2008, 3, 185-193. [CrossRef]

80. Li, L.H.; Kong, Y.M.; Kim, H.W.; Kim, Y.W.; Kim, H.E.; Heo, S.J.; Koak, J.Y. Improved biological performance of Ti implants due to surface modification by micro-arc oxidation. Biomaterials 2004, 25, 2867-2875. [CrossRef] [PubMed]

81. Zhao, Z.; Chen, X.; Chen, A.; Shen, M.; Wen, S. Synthesis of bioactive ceramic on the titanium substrate by micro-arc oxidation. J. Biomed. Mater. Res. A 2009, 90, 438-445. [CrossRef] [PubMed]

82. Song, W.H.; Jun, Y.K.; Han, Y.; Hong, S.H. Biomimetic apatite coatings on micro-arc oxidized titania. Biomaterials 2004, 25, 3341-3349. [CrossRef] [PubMed]

83. Sun, J.; Han, Y.; Huang, X. Hydroxyapatite coatings prepared by micro-arc oxidation in Ca- and P-containing electrolyte. Surf. Coat. Technol. 2007, 201, 5655-5658. [CrossRef]

84. Chen, W.; Liu, Y.; Courtney, H.S.; Bettenga, M.; Agrawal, C.M.; Bumgardner, J.D.; Ong, J.L. In vitro anti-bacterial and biological properties of magnetron co-sputtered silver-containing hydroxyapatite coating. Biomaterials 2006, 27, 5512-5517. [CrossRef] [PubMed]

85. Boyan, B.D.; Batzer, R.; Kieswetter, K.; Liu, Y.; Cochran, D.L.; Szmuckler-Moncler, S.; Dean, D.D.; Schwartz, Z. Titanium surface roughness alters responsiveness of MG63 osteoblast-like cells to $1 \alpha, 25-(\mathrm{OH})_{2} \mathrm{D}_{3}$. J. Biomed. Mater. 1998, 39, 77-85. [CrossRef]

86. Naveena, N.; Venugopal, J.; Rajeswari, R.; Sundarrajan, S.; Sridhar, R.; Shayanti, M.; Narayanan, S.; Ramakrishna, S. Biomimetic composites and stem cells interaction for bone and cartilage tissue regeneration. J. Mater. Chem. 2012, 22, 5239-5253. [CrossRef]

87. Jamuna-Thevi, K.; Bakar, S.A.; Ibrahim, S.; Shahab, N.; Toff, M.R.M. Quantification of silver ion release, in vitro cytotoxicity and antibacterial properties of nanostuctured $\mathrm{Ag}$ doped $\mathrm{TiO}_{2}$ coatings on stainless steel deposited by rf magnetron sputtering. Vacuum 2011, 86, 235-241. [CrossRef]

88. Brammer, K.S.; Oh, S.; Cobb, C.J.; Bjursten, L.M.; van der Heyde, H.; Jin, S. Improved bone-forming functionality on diameter-controlled $\mathrm{TiO}_{2}$ nanotube surface. Acta Biomater. 2009, 5, 3215-3223. [CrossRef] [PubMed]

89. Oh, S.; Daraio, C.; Chen, L.H.; Pisanic, T.R.; Finones, R.R.; Jin, S. Significantly accelerated osteoblast cell growth on aligned $\mathrm{TiO}_{2}$ nanotubes. J. Biomed. Mater. Res. A 2006, 78, 97-103. [CrossRef] [PubMed]

90. Von Wilmowsky, C.; Bauer, S.; Lutz, R.; Meisel, M.; Neukam, F.W.; Toyoshima, T.; Schmuki, P.; Nkenke, E.; Schlegel, K.A. In vivo evaluation of anodic $\mathrm{TiO}_{2}$ nanotubes: An experimental study in the pig. J. Biomed. Mater. Res. B Appl. Biomater. 2009, 89, 165-171. [CrossRef] [PubMed]

91. Gao, A.; Hang, R.; Huang, X.; Zhao, L.; Zhang, X.; Wang, L.; Tang, B.; Ma, S.; Chu, P.K. The effects of titania nanotubes with embedded silver oxide nanoparticles on bacteria and osteoblasts. Biomaterials 2014, 35, 4223-4235. [CrossRef] [PubMed]

92. Kim, M.S.; Ryu, J.J.; Sung, Y.M. One-step approach for nano-crystalline hydroxyapatite coating on titanium via micro-arc oxidation. Electrochem. Commun. 2007, 9, 1886-1891. [CrossRef] 
93. Ni, J.H.; Shi, Y.L.; Yan, F.Y.; Chen, J.Z.; Wang, L. Preparation of hydroxyapatite-containing titania coating on titanium substrate by micro-arc oxidation. Mater. Res. Bull. 2008, 43, 45-53. [CrossRef]

94. Han, Y.; Chen, D.; Sun, J.; Zhang, Y.; Xu, K. UV-enhanced bioactivity and cell response of micro-arc oxidized titania coatings. Acta Biomater. 2008, 4, 1518-1529. [CrossRef] [PubMed]

95. Hang, R.; Gao, A.; Huang, X.; Wang, X.; Zhang, X.; Qin, L.; Tang, B. Antibacterial activity and cytocompatibility of Cu-Ti-O nanotubes. J. Biomed. Mater. Res. A 2014, 102, 1850-1858. [CrossRef] [PubMed]

96. Zong, M.; Bai, L.; Liu, Y.; Wang, X.; Zhang, X.; Huang, X.; Hang, R.; Tang, B. Antibacterial ability and angiogenic activity of Cu-Ti-O nanotube arrays. Mater. Sci. Eng. C 2017, 71, 93-99. [CrossRef] [PubMed]

97. Burghardt, I.; Luthen, F.; Prinz, C.; Kreikemeyer, B.; Zietz, C.; Neumann, H.G.; Rychly, J. A dual function of copper in designing regenerative implants. Biomaterials 2015, 44, 36-44. [CrossRef] [PubMed]

98. Ramaswamy, Y.; Wu, C.; Zhou, H.; Zreiqat, H. Biological response of human bone cells to zinc-modified Ca-Si-based ceramics. Acta Biomater. 2008, 4, 1487-1497. [CrossRef] [PubMed]

99. Raghupathi, K.R.; Koodali, R.T.; Manna, A.C. Size-dependent bacterial growth inhibition and mechanism of antibacterial activity of zinc oxide nanoparticles. Langmuir 2011, 27, 4020-4028. [CrossRef] [PubMed]

100. Boyd, D.; Li, H.; Tanner, D.A.; Towler, M.R.; Wall, J.G. The antibacterial effects of zinc ion migration from zinc-based glass polyalkenoate cements. J. Mater. Sci. Mater. Med. 2006, 17, 489-494. [CrossRef] [PubMed]

101. Wu, C.; Ramaswamy, Y.; Chang, J.; Woods, J.; Chen, Y.; Zreiqat, H. The effect of Zn contents on phase composition, chemical stability and cellular bioactivity in Zn-Ca-Si system ceramics. J. Biomed. Mater. Res. B Appl. Biomater. 2008, 87, 346-353. [CrossRef] [PubMed]

102. Ibănescu, M.; Muşat, V.; Textor, T.; Badilita, V.; Mahltig, B. Photocatalytic and antimicrobial Ag/ZnO nanocomposites for functionalization of textile fabrics. J. Alloys Compd. 2014, 610, 244-249. [CrossRef]

103. Li, J.; Liu, X.; Qiao, Y.; Zhu, H.; Ding, C. Antimicrobial activity and cytocompatibility of Ag plasma-modified hierarchical $\mathrm{TiO}_{2}$ film on titanium surface. Colloids Surf. B Biointerfaces 2014, 113, 134-145. [CrossRef] [PubMed]

104. Mohapatra, S. Tunable surface plasmon resonance of silver nanoclusters in ion exchanged soda lime glass. J. Alloys Compd. 2014, 598, 11-15. [CrossRef]

105. Kim, T.; Yoshitake, M.; Yagyu, S.; Nemsak, S.; Nagata, T.; Chikyow, T. XPS study on band alignment at Pt-O-terminated $\mathrm{ZnO}(0001)$ interface. Surf. Interface Anal. 2010, 42, 1528-1531. [CrossRef]

106. Carvalho, P.; Sampaio, P.; Azevedo, S.; Vaz, C.; Espinós, J.P.; Teixeira, V.; Carneiro, J.O. Influence of thickness and coatings morphology in the antimicrobial performance of zinc oxide coatings. Appl. Surf. Sci. 2014, 307, 548-557. [CrossRef]

107. Cao, H.; Liu, X.; Meng, F.; Chu, P.K. Biological actions of silver nanoparticles embedded in titanium controlled by micro-galvanic effects. Biomaterials 2011, 32, 693-705. [CrossRef] [PubMed]

108. Bai, L.; Hang, R.; Gao, A.; Zhang, X.; Huang, X.; Wang, Y.; Tang, B.; Zhao, L.; Chu, P.K. Nanostructured titanium-silver coatings with good antibacterial activity and cytocompatibility fabricated by one-step magnetron sputtering. Appl. Surf. Sci. 2015, 355, 32-44. [CrossRef]

109. Gao, A.; Hang, R.; Chu, P.K. Recent advances in anti-infection surfaces fabricated on biomedical implants by plasma-based technology. Surf. Coat. Technol. 2016, 312, 2-6. [CrossRef]

110. Zhang, X.; Hang, R.; Wu, H.; Huang, X.; Ma, Y.; Lin, N.; Yao, X.; Tian, L.; Tang, B. Synthesis and antibacterial property of Ag-containing $\mathrm{TiO}_{2}$ coatings by combining magnetron sputtering with micro-arc oxidation. Surf. Coat. Technol. 2013, 235, 748-754. [CrossRef]

111. Zhang, X.; Wu, H.; Geng, Z.; Huang, X.; Hang, R.; Ma, Y.; Yao, X.; Tang, B. Microstructure and cytotoxicity evaluation of duplex-treated silver-containing antibacterial $\mathrm{TiO}_{2}$ coatings. Mater. Sci. Eng. C Mater. Biol. Appl. 2014, 45, 402-410. [CrossRef] [PubMed]

112. He, X.; Zhang, X.; Bai, L.; Hang, R.; Huang, X.; Qin, L.; Yao, X.; Tang, B. Antibacterial ability and osteogenic activity of porous $\mathrm{Sr} / \mathrm{Ag}$-containing $\mathrm{TiO}_{2}$ coatings. Biomed. Mater. 2016, 11, 045008. [CrossRef] [PubMed]

(C) 2017 by the authors. Licensee MDPI, Basel, Switzerland. This article is an open access article distributed under the terms and conditions of the Creative Commons Attribution (CC BY) license (http:/ / creativecommons.org/licenses/by/4.0/). 